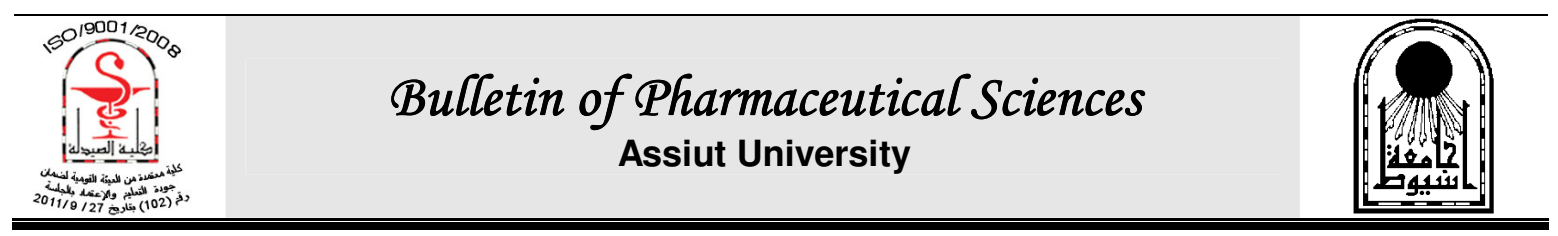

\title{
MACRO- AND MICROMORPHOLOGY OF THE LEAVES, INFLORESCENCES AND FRUITS OF FICUS SYCOMORUS L. CULTIVATED IN EGYPT: PART 1
}

\author{
S. M. El-Sayyad, M. A. Makboul, S. F. Farag and R. M. Ali \\ Department of Pharmacognosy, Faculty of Pharmacy, Assiut University, Assiut, Egypt
}

\begin{abstract}
Ficus sycomorus L. (gimmeiz) belongs to family Moraceae. The leaves and fruits have been used in the treatment of tuberculosis, inflammations, dysentery, diarrhea, cough and chest diseases. No detailed information could be traced concerning the macro-and micromorphology of the leaves, inflorescences and fruits of the plant, so this study is performed with the aim of finding their characters by which they could be identified and differentiated, in both the entire and powdered forms.
\end{abstract}

\section{INTRODUCTION}

The family Moraceae (Mulberry Family) includes about 73 genera and 1000 species. The members of family Moraceae are mainly tropical or subtropical, monoecious or dioecious trees, shrubs or herbs, with milky latex ${ }^{1-3}$.

The significant features of the genus Ficus include that the leaves are alternate (rarely opposite), simple with entire, serrate or lobed margins, 2 stipules which are small and lateral or each pair forming a cap over the bud and leaving a cylindrical scar. The inflorescence is basically cymose but often modified. The flower is unisexual, minute and regular. Fruit is syconus formed of an achene within a fleshy receptacle $^{1 \& 3}$. Isoprenoids, steroids, hydrocarbons, flavonoids, coumarins, furocoumarins, lignans, stilbenes, phenylpropanoids, ceramides and alkaloids have been reported as chemical constituents of different Ficus species ${ }^{4-11}$.

Ficus sycomorus L. is cultivated in Egypt and called sycamore or gimmeiz ${ }^{12 \& 13}$. The fig never produces ripe seeds in Egypt ${ }^{13}$. The comparatively large fruit is edible and the plant is used as folk remedies in various African countries. The extracts of the fruits, leaves, stem and root barks usually administered in the form of infusions, decoctions, tinctures, syrups and lotions have been used in the treatment of many diseases and disorders such as tuberculosis, inflammations, dysentery, diarrhea, cough, chest and mental disorders, skin infections and helminthiasis ${ }^{14 \& 15}$. Also, the plant was reported to have antimicrobial ${ }^{16-18}$, analgesic and anti-inflammatory ${ }^{19}$, antidiarrheal $^{20}$, antioxidant ${ }^{21}$, hepatoprotective ${ }^{15 \& 22}$, sedative and anticonvulsant ${ }^{23}$, antitumor ${ }^{24}$, antidiabetic ${ }^{25}$ and muscle relaxant activities ${ }^{26}$ in addition to insecticidal and acaricidal properties $^{27}$.

\section{Habitat}

Ficus sycomorus L. (F. Moraceae) is native to Mediterranean, tropical and subtropical regions. The tree (Fig. 1) is large evergreen, attaining up to 20 meters in height, usually contains latex. The leaves are petioled, simple, alternate, coriaceous, pubescent on the lower surface especially along the nerves, ovate, with symmetric cordate bases, rounded or obtuse apices and entire margins. Fruits are in crowded grapes on the trunks and old branches, obovoid to depressed-spherical, tomentose; ripen several times a year, mainly in summer. The fruit is syconium consists of numerous small male and female flowers arranged inside a hollow fleshy receptacle and an opening at the top through which insects pass to pollinate the minute flowers. The fig is sweet, juicy, edible and reddish-brown when ripe $^{12 \& 13}$. 


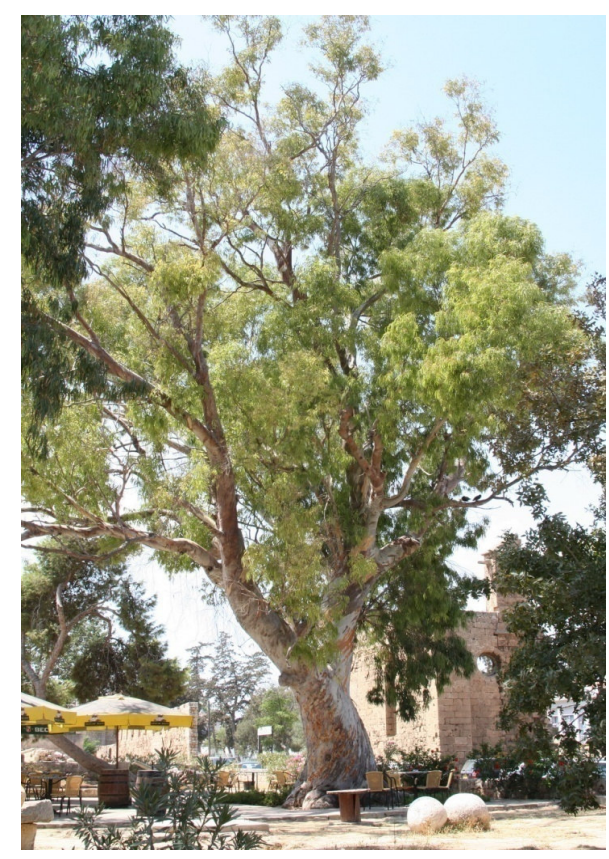

Fig. 1: Photo of the plant.

\section{Material}

Fresh samples of $F$. sycomorus L. leaves, inflorescences and fruits were collected during the flowering stage in the period of February to April 2010, from the Experimental Station of Ornamental Plants, Faculty of Agriculture, Assiut University and kindly identified and authenticated by Prof. Dr. Naeem E. Keltawy (the late), Professor of Ornamental Horticulture and Floriculture, Faculty of Agriculture, Assiut University. Different organ samples were preserved in a mixture of alcohol (70\%)glycerin-water $(1: 1: 1 \mathrm{v} / \mathrm{v})$ and stored in a tightly closed container, other samples were separately air-dried and reduced to fine powder.

\section{THE LEAF}

\section{A- Macromorphology (Fig. 2A,B\&C)}

The Leaves are petioled, alternate, simple, coriaceous, pubescent on the lower surface especially along the nerves, broadly ovate, exstipulate with entire or slightly repanddentate margins, rounded or obtuse apices and symmetric cordate bases. The upper surface is dark green in color while the lower one is lighter with prominent yellow midrib. The vennation is pinnate reticulate. The veins are prominent on the lower surface with 5-7 pairs of yellow lateral veins; the lowest pair originates at the leaf base. The leaf measures about (4- $-6-9) \mathrm{cm}$ in length and $(3-\underline{5}-8) \mathrm{cm}$ in width at the widest part. The petiole is nearly cylindrical, pubescent, green in color and measures about (1-2-4) $\mathrm{cm}$ in length and (2-3) $\mathrm{mm}$ in diameter. The leaf has very faint odor and taste.

\section{B- Micromorphology \\ 1- The lamina (Fig. 3A)}

A transverse section of the lamina in the midrib region is biconvex to plano-convex in outline; the midrib is more prominent on the lower surface. The leaf is dorsiventral with an upper palisade of 2-3 rows which is discontinuous in the midrib region where it is replaced by collenchyma followed by parenchyma. The upper epidermis of lamina is multiple $^{28}$ and parenchymatous. The vascular system in the midrib region is represented by a large crescent-shaped main dissected vascular bundle accompanied by several additives and inverted smaller ones oriented to form a dissected ring enclosing central parenchyma. The latter contains groups of interxyllary phloem and few small vascular bundles. All the system is surrounded by a pericycle formed of a ring of groups of fibres interrupted by parenchyma $^{29}$. Both the upper and lower epidermises are covered with glandular and non-glandular hairs.

\section{The epidermis}

Upper epidermis: In transverse section the upper epidermis (Figs. 3E\&4) shows 1-3 rows of square to sub-rectangular, thin-walled cellulosic cells covered with thick cuticle ${ }^{28}$. While, in surface view (Fig. 3B) the cells appear polygonal, isodiametric to slightly elongated with straight anticlinal walls and covered with smooth cuticle. Stomata are absent. The covering trichomes are unicellular of various sizes and shapes. Some of them are short, conical with wide bases while the others are long having narrow bases and sometimes curved. Glandular trichomes have globular bicellular (divided vertically) ${ }^{29}$ or multicellular heads from 3 to 4 cells and unicellular or bicellular or multicellular uniseriate stalks. Some of the epidermal cells show gland (cystolith) having cellulosic stalk that carries precipitated calcium carbonate abutting on the upper epidermis that shows effervescence after addition of $\mathrm{HCl}^{13,28 \& 30}$. 
Lower epidermis: In transverse section the lower epidermis (Figs. 3E\&4) is formed of one row of rectangular to sub-rectangular cells covered with thin cuticle. In surface view (Fig. 3C), the cells appear isodiametric to elongated cells with sinuous thin anticlinal walls and covered with striated cuticle. Numerous stomata of the anomocytic type are present. Abundant glandular and non-glandular trichomes exactly similar to those of the upper epidermis are present. In addition, long clothing hairs are observed have basal pedestals of epidermal cells ${ }^{30}$. Glands are also observed.

Both of the upper and lower neural epidermises are nearly similar in surface view (Fig. 3D), being polygonal, usually axially elongated with straight anticlinal walls and covered with smooth cuticle.

\section{The mesophyll (Fig. 3E)}

The mesophyll is heterogeneous consisting of an upper zone of 2-3 rows of palisade layer interrupted by a mass of collenchymatous cells in the midrib region. The spongy tissue is formed of 3-5 rows of more or less rounded, ovoid or irregular thin-walled parenchyma cells with wide intercellular spaces.

\section{The cortical tissue (Fig. 4)}

The cortical tissue consists of 6-8 rows of nearly rounded collenchyma cells followed by 3-5 rows of oval to rounded parenchyma cells. They contain starch granules in addition to prisms and clusters of calcium oxalate crystals. Frequent cells contain phenolic substances which stain dark blue with aqueous solution of $\mathrm{FeCl}_{3}$ are scattered in the parenchymatous zone $^{30}$.

\section{The pericycle (Fig. 4)}

The pericyclic fibers have moderately thick lignified walls, narrow to moderately wide lumina, acute to rounded apices. Sclereides are rare and if present they are single, irregularly rectangular to subrectangular in shape with evenly thickened lignified walls.

\section{The vascular system (Fig. 4) The phloem}

It is formed of cellulosic elements, hardly distinguishable. Some phloem parenchyma contains cluster crystals of calcium oxalate. Small latex tubes are scattered contain granular content stained yellowish-brown with iodine solution $^{30}$. Phloem and xylem are separated by 1-2 rows of cambial cells.

\section{The xylem (Fig. 4)}

The xylem is lignified consists of vessels, wood fibers, wood parenchyma and tracheids followed by 1-2 rows of rectangular pitted lignified parenchyma. The vessels have spiral, scalariform and pitted thickening. The wood fibers are few, septated with thick pitted lignified walls, narrow lumina and rounded to acute apices. The tracheids are elongated and lignified with blunt or pointed ends, bearing simple pits. Wood parenchyma consists of rectangular to sub-rectangular cells with thick lignified pitted walls. Medullary rays are uniseriate and formed of radially elongated cells. Few pitted lignified parenchyma cells are scattered beneath the xylem region and around the interxyllary phloem.

\section{2- The petiole (Fig. 5A)}

The transverse section through the petiole is nearly circular in outline. It shows a multiple epidermis ${ }^{28}$ formed of parenchymatous cells. The cortex shows about 6-8 rows of collenchyma cells followed by parenchyma. The pericycle consists of alternating groups of pericyclic fibers and parenchyma. Few sclereides are present. The vascular system is formed of dissected bundles; each consists of a radiating xylem and outer phloem enclosing comparatively wide pith. Groups of interxyllary phloem and few small vascular bundles are scattered at the periphery of the pith.

\section{The epidermis}

It consists of 1-3 rows of isodiametric to sub-rectangular cells in transverse section (Fig. $6)$ which contain brown pigment and covered with thick smooth cuticle. In surface view (Fig. 5B), the upper row cells are sometimes elongated with thin straight anticlinal walls. Numerous unicellular non-glandular trichomes of different size are present. Also, long clothing hairs similar to those of the lower epidermis of the lamina are observed. Stomata are not observed. 


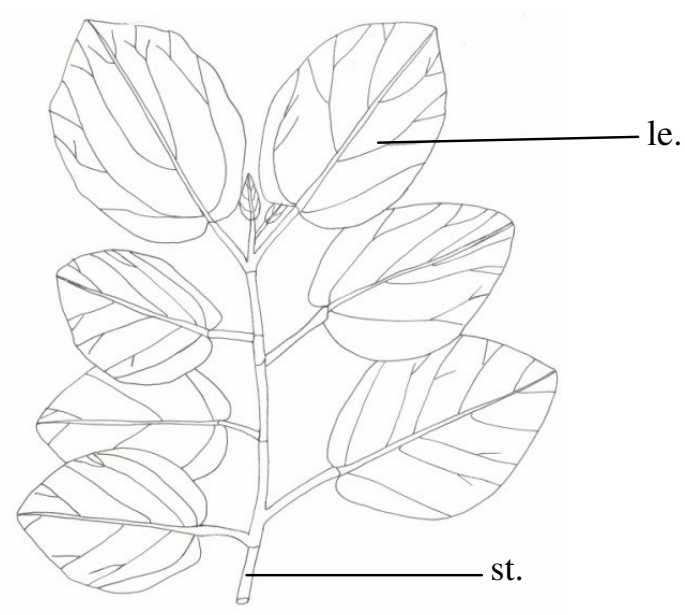

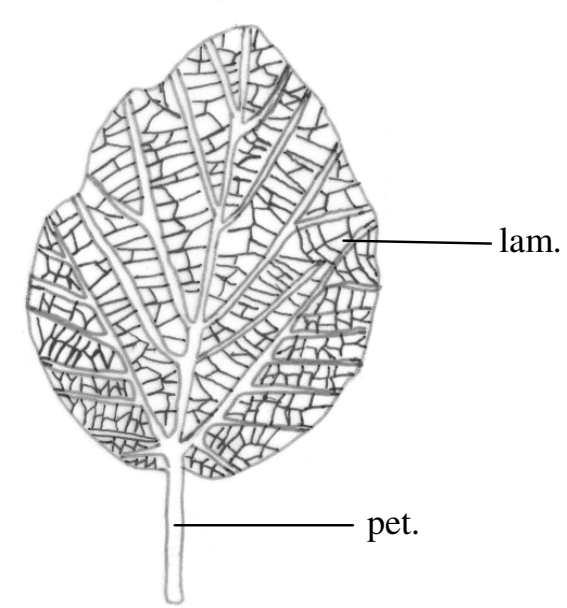

(B)

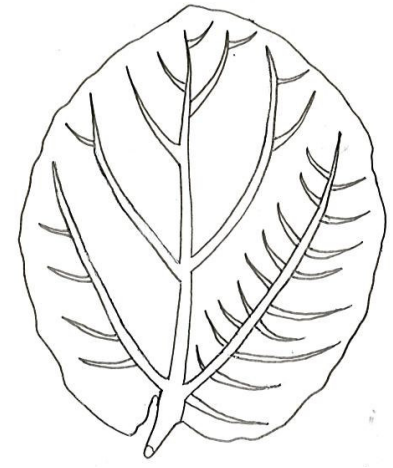

(C)

Fig. 2: (A) Macromorphology of the branch.

$\times 0.25$

(B) Macromorphology of the upper surface of the leaf.

$\mathrm{x} 0.5$

(C) Macromorphology of the lower surface of the leaf.

x 0.5

la., lamina; le., leaf; pet., petiole; st., stem. 

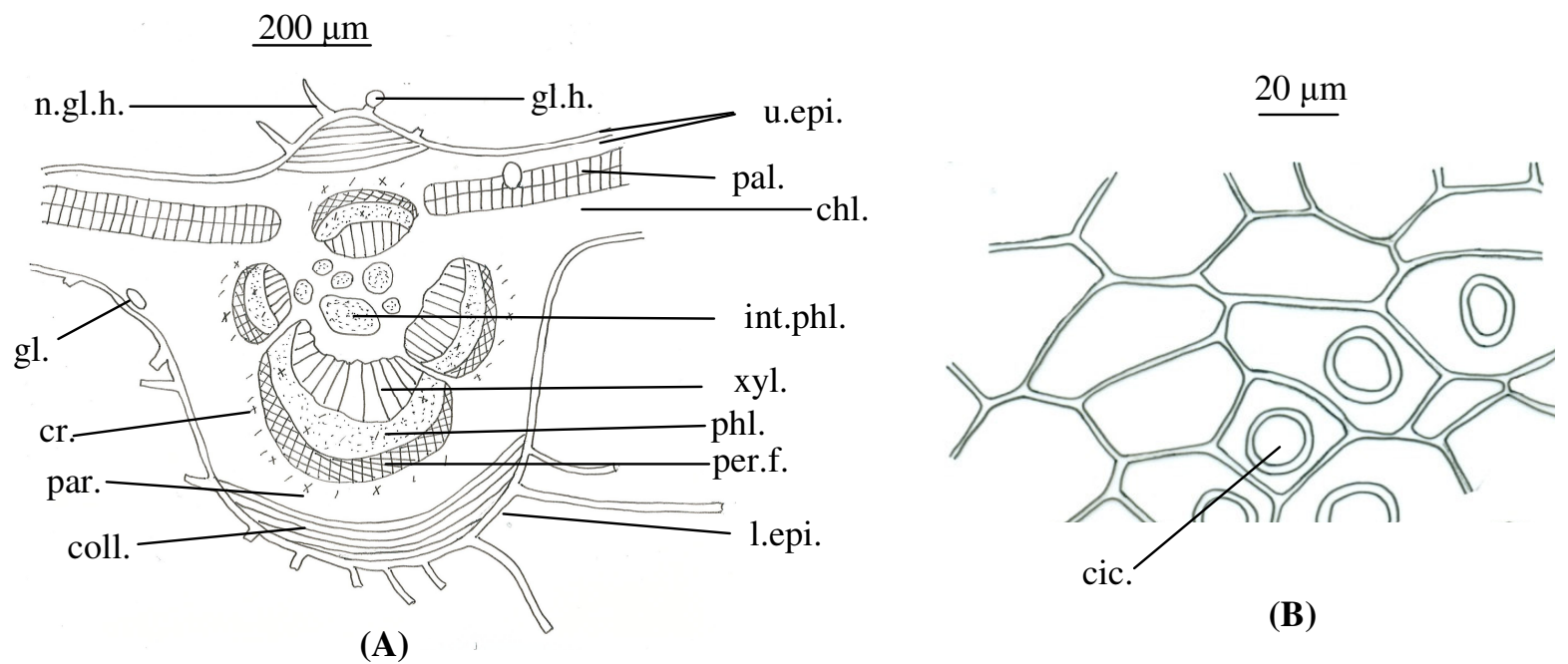

(A)

(B)

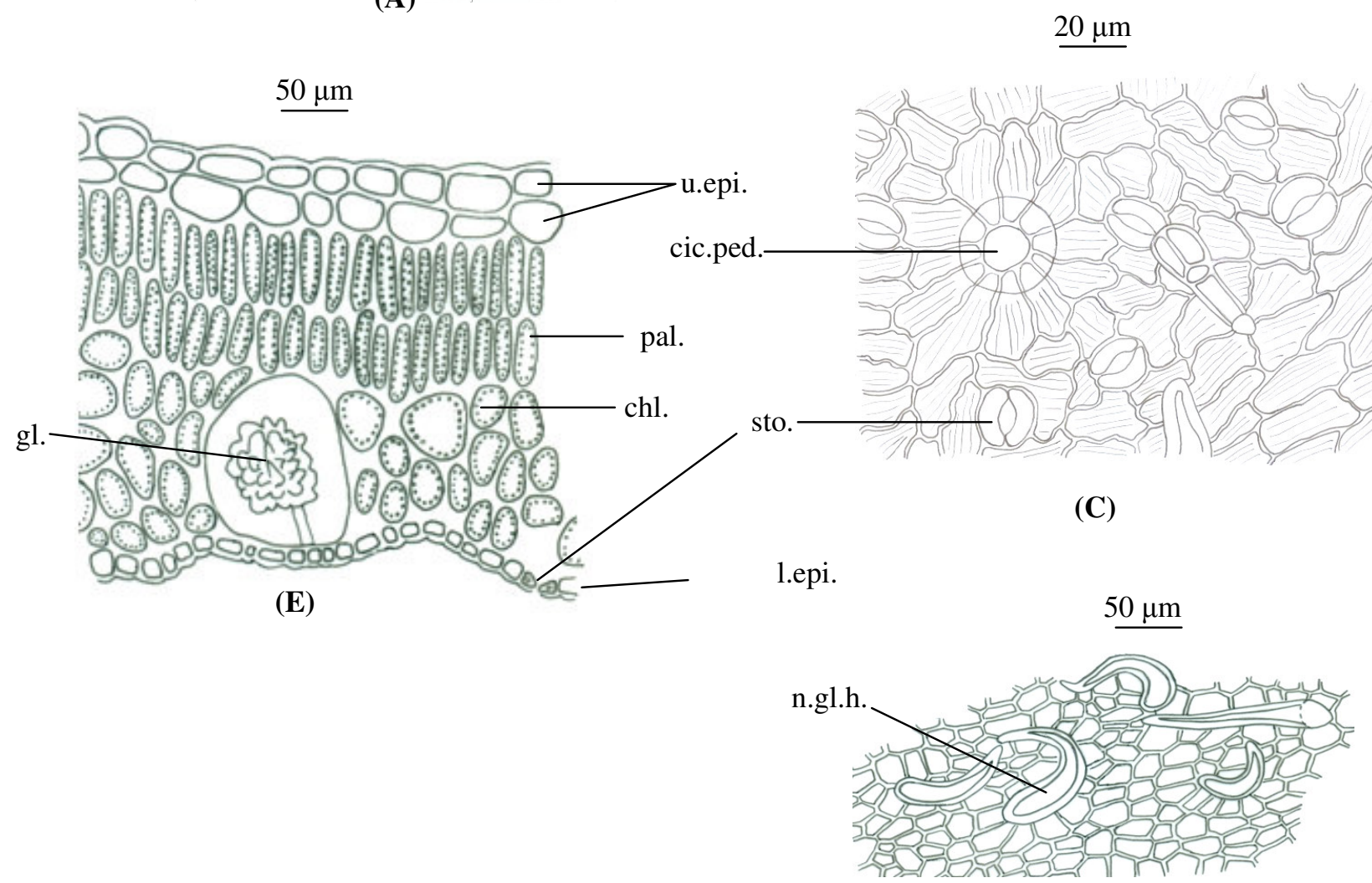

Fig. 3: (A) Diagrammatic T.S of the leaf.

(D)

(B) Upper epidermis of the leaf.

(C) Lower epidermis of the leaf.

(D) Neural epidermis of the leaf.

(E) Detailed T.S. in the lamina.

chl., chlorenchyma; cic., cicatrix; cic. ped., cicatrix pedastale; coll., collenchyma; cr., crystal of cacium oxalate; gl., gland; gl.h., glandular hair; int.phl., interxyllary phloem; l.ep., lower epidermis; n.gl.h., non-glandular hair; pal., palisade; par., parenchyma; per.f., pericyclic fiber; phl., phloem; sto., stomata; u.ep., upper epidermis; xyl., xylem. 


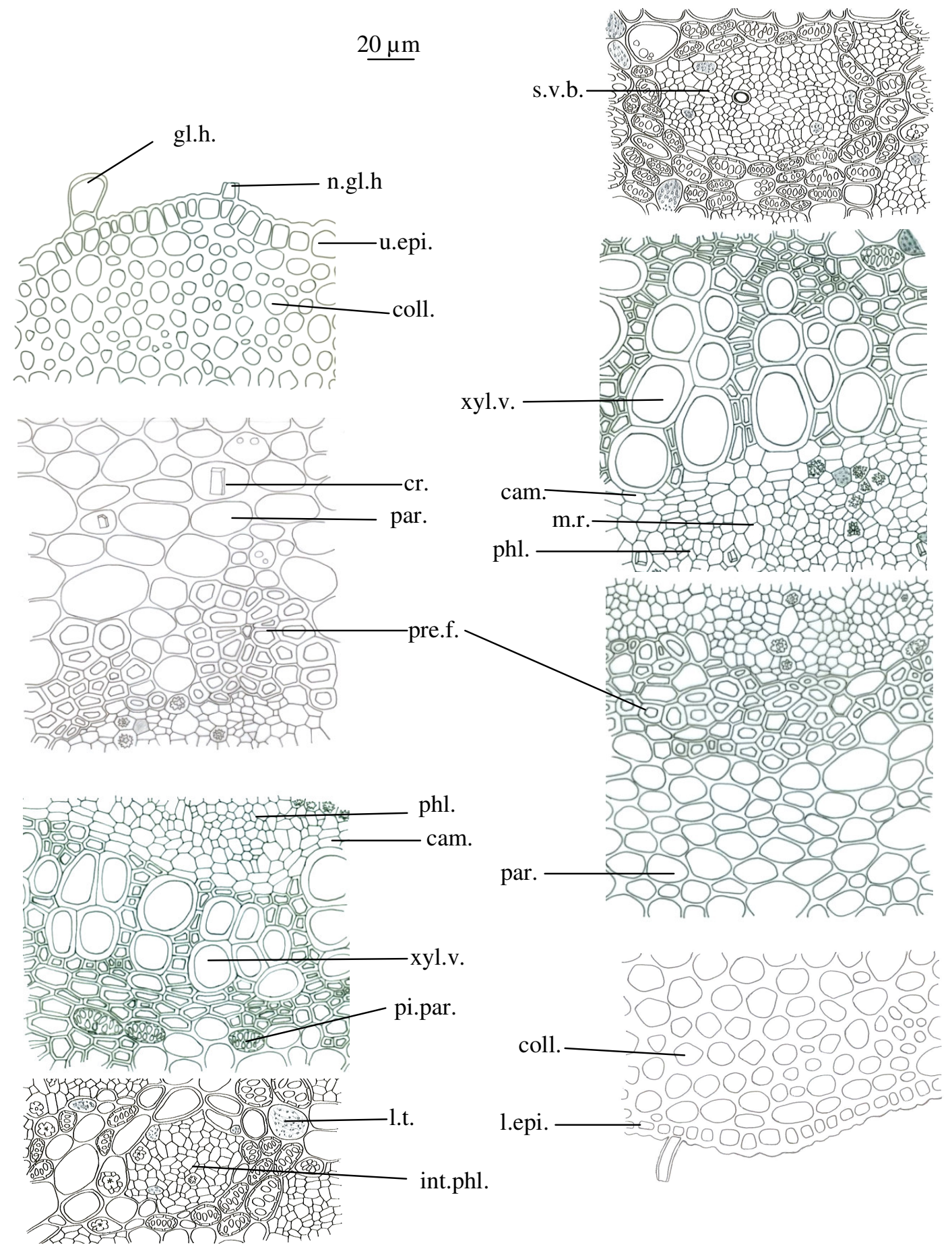

Fig. 4: Detailed T.S in the midrib region.

cam., cambium; coll., collenchyma; cr., crystal of calcium oxalate.; gl.h., glandular hair; int.phl., interxyllary phloem; 1.t., laticiferous tube; l.ep., lower epidermis; m.r., medullary ray; n.gl.h., nonglandular hair; par., parenchyma; p.f., pericyclic fiber; phl., phloem; pi.par., pitted parenchyma; s.v.b., small vascular bundle; u.ep., upper epidermis; xyl.v., xylem vessels. 

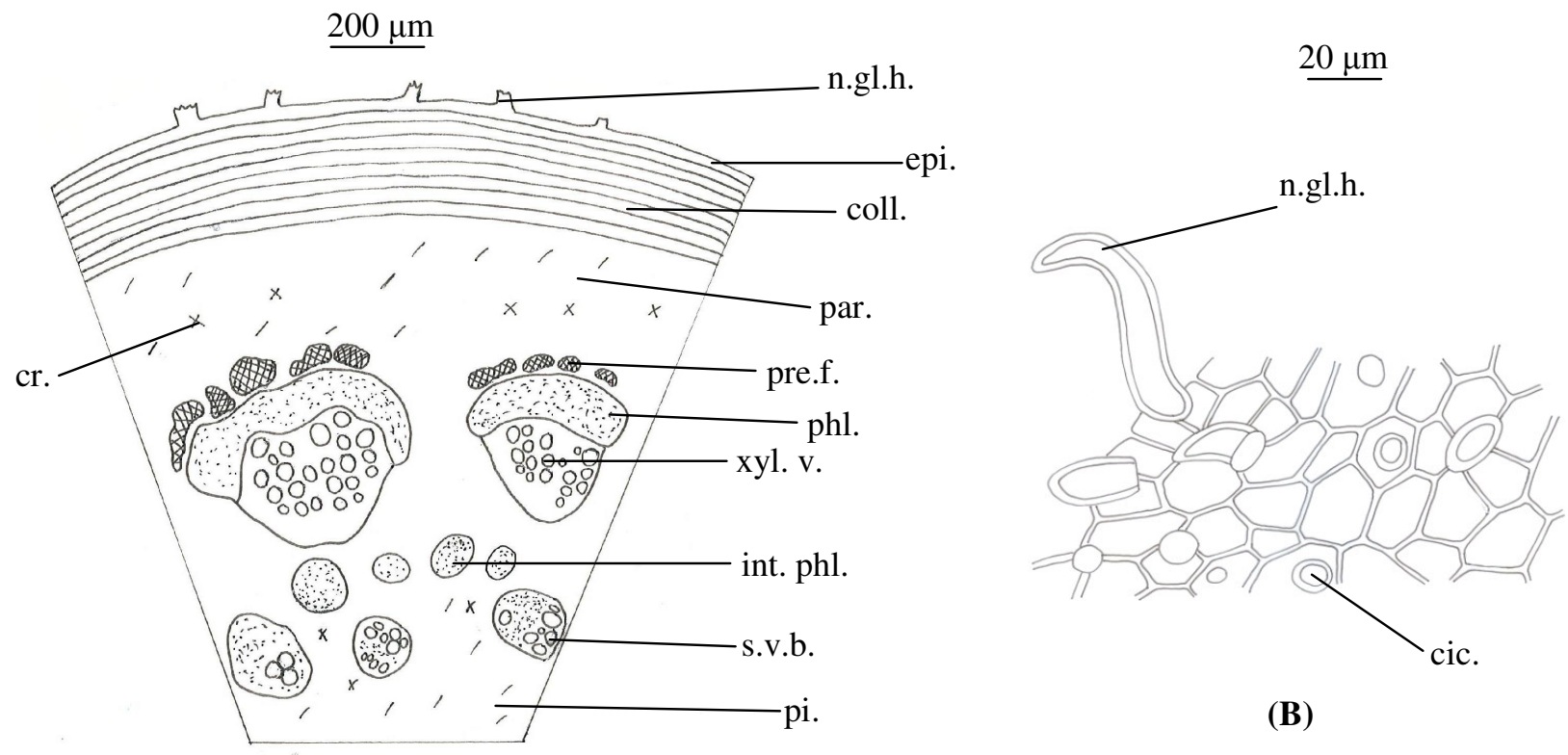

(B)

(A)

Fig. 5: (A) Diagrammatic T.S. of the petiole.

(B) Epidermis of the petiole.

cic., cicatrix; coll., collenchyma; cr., crystal of calcium oxalate.; ep., epidermis; int.phl., interxyllary phloem; n.gl.h., non-glandular hair; par., parenchyma; per.f., pericyclic fiber; phl., phloem; pi., pith; s.v.b., small vascular bundle; xyl.v., xylem vessel.

\section{The cortex (Fig. 6)}

It consists of an outer zone of (6-8) rows of nearly rounded collenchyma cells followed by a zone of (5-9) rows of oval to rounded parenchymatous cells containing starch granules in addition to prisms and cluster crystals of calcium oxalate. Frequent cells contain phenolic substance also few latex tubes are scattered.

\section{The pericycle (Figs. $6 \& 7$ )}

Pericyclic fibers have moderately thick lignified walls, wide lumina and blunt to rounded apices. Few sclereides are present, which are single, irregularly rectangular to subrectangular in shape with evenly thickened lignified walls.

\section{The vascular system (Fig. 6)}

The vascular bundle is exactly similar to that of the lamina.
The powder and isolated elements (Fig. 7)

The powdered leaf has a dark green color, faint odor and taste. It is characterized microscopically by the presence of the following fragments:

1- Fragments of the upper epidermis of the lamina which appear polygonal isodiametric to slightly elongated with straight anticlinal walls covered with thin cuticle. Stomata are absent.

2- Fragments of lower epidermis of the lamina which appear polygonal, nearly isodiametric to elongated cells with sinuous anticlinal walls, covered with striated cuticle. Numerous stomata of the anomocytic type are present that surrounded by 4 to 5 epidermal cells. They are rounded to oval in shape.

3- Few trichomes of both glandular and nonglandular types are present. The covering trichomes are unicellular of various sizes and shapes. Some of them are short, 

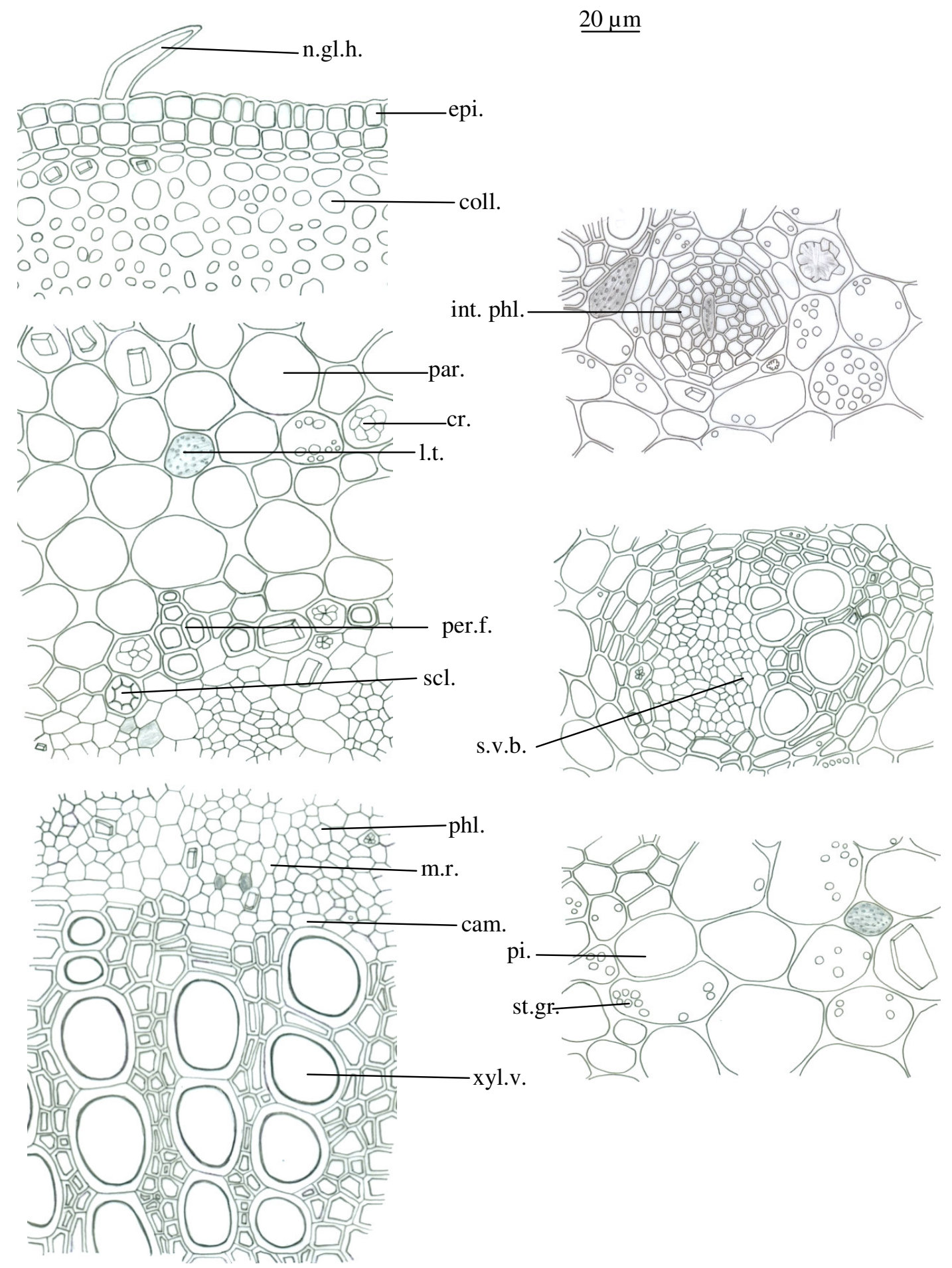

Fig. 6: Detailed T.S. of the petiole.

coll., collenchyma; cr., crystal of calcium oxalate.; epi., epidermis; int.phl., interxyllary phloem; 1.t., laticiferous tube; m.r., medullary rays; n.gl.h., non-glandular hair; par. parenychyma; per.f., pericyclic fiber; phl., phloem; pi., pith; sc., sclereides; s.v.b., small vascular bundle; st.gr., starch granules; xyl.v., xylem vessel. 


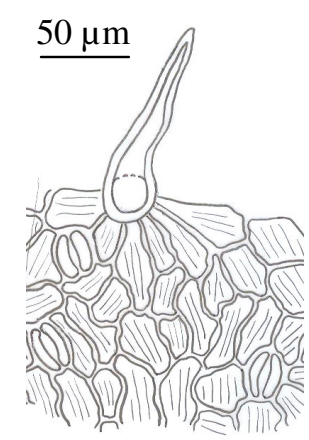

l.ep.

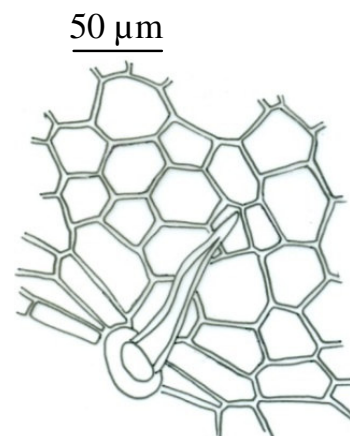

u.ep.

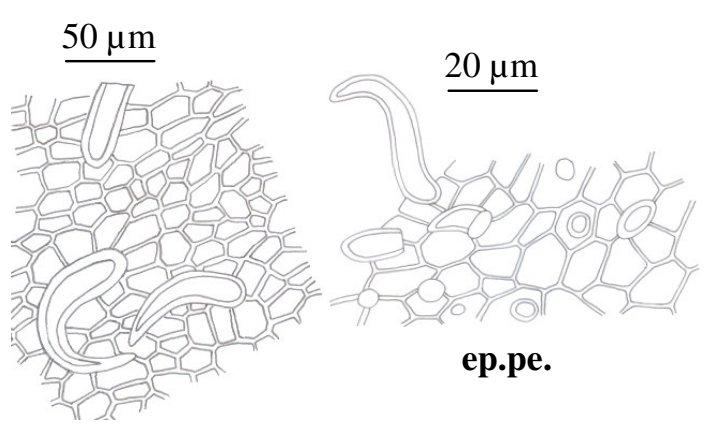

n.ep.

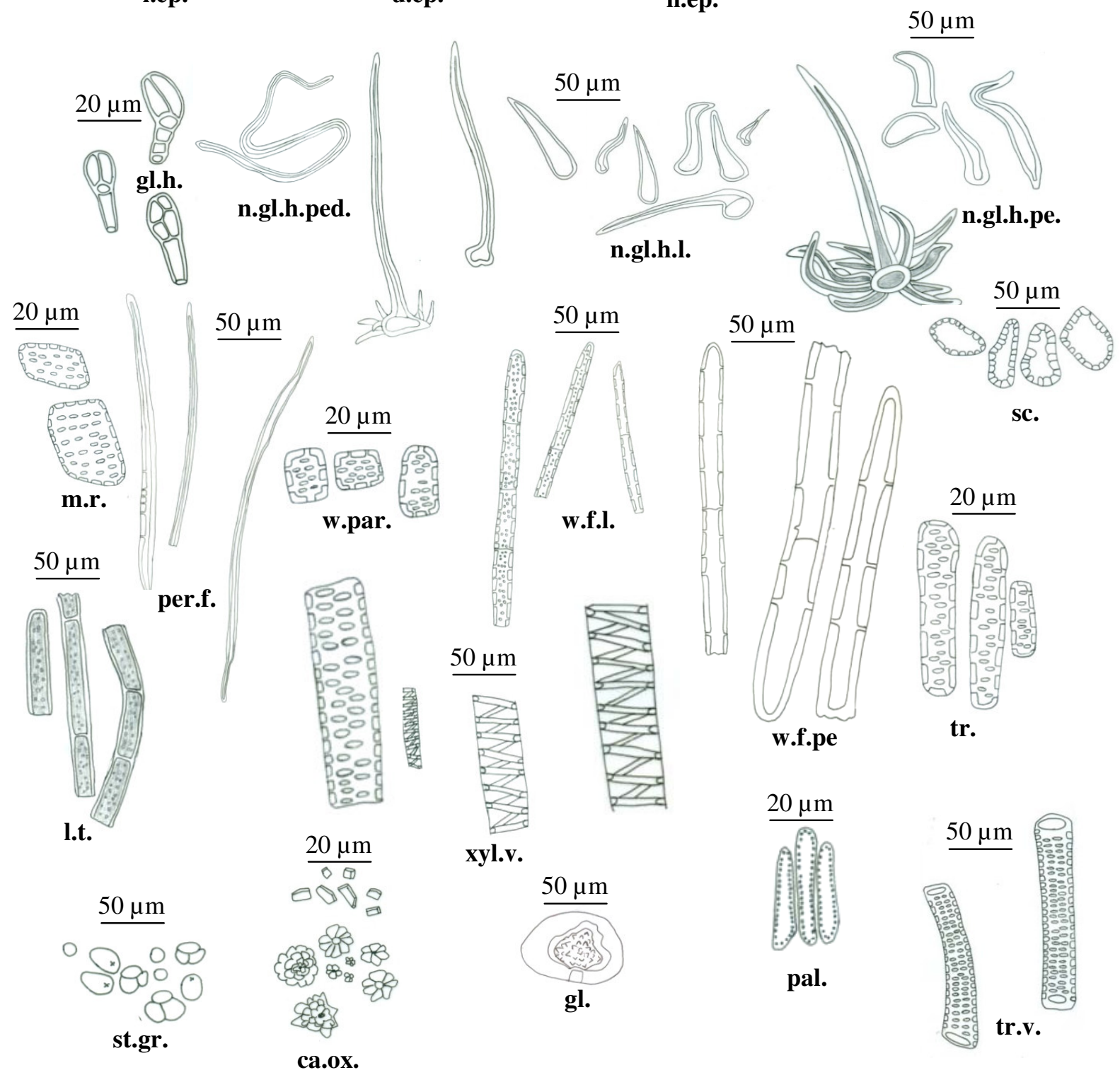

Fig. 7: Powder and isolated elements of the leaf.

ca.ox., calcium oxalate crystals; cic., cicatrix; ep.pet., epidermis of petiole; gl., gland; gl.h., glandular hair; l.t., laticiferous tube; l.ep., lower epidermis; m.r., medullary ray cells; ne.ep., neural epidermis; n.gl.h.l, nonglandular hair of lamina; n.gl.h.pe., non-glandular hair of petiol; n.gl.h.ped., non-glandular hair pedestals; pal., palisade; per.f., pericyclic fiber; sc., sclereides; st.gr., starch granules; tr., tracheids; tr.v., tracheidal vessels; u.ep., upper epidermis; w.f.l., wood fiber of lamina; w.f.pe., wood fiber of petiole; w.par., wood parenchyma; xyl.v., xylem vessel. 
conical in shape have wide bases while the others are long have narrow bases and sometimes curved. The glandular trichomes have globular bicellular or multicellular heads from 3 to 4 cells and unicellular or bicellular or multicellular uniseriate stalks.

4- Fragments of the neural epidermis which appear polygonal axially elongated cells with straight anticlinal walls, covered with smooth cuticle and showing cicatrices of covering trichomes.

5- Scattered entire or fragments of glandular and non-glandular hairs.

6- Fragments of the epidermis of the petiole showing polygonal mostly subrectangular, elongated with straight anticlinal walls, covered with thick smooth cuticle and contain brown pigment. Hairs of both glandular and nonglandular types exactly identical to those of the upper epidermis of the lamina.

7- Fragments of lignified spiral, scalariform and pitted xylem vessels.

8- Fragments of pericyclic fibers with moderately thick lignified walls, narrow to moderately wide lumina and acute to rounded apices.

9- Fragments of mesophyll tissue with green columnar palisade cells and spongy parenchyma.

10- Fragments of rectangular to subrectangular cells, lignified pitted wood parenchyma and medullary ray cells.

11- Fragments of elongated lignified pitted tracheids and tracheidal vessels with blunt or pointed ends.

12- Fragments of wood fibers of the lamina which are septated with thick pitted lignified walls, narrow lumina and rounded to acute apices.

13- Fragments of wood fibers of the petiole which are septated, fusiform in shape with thick lignified walls, moderate wide lumina and acute apices.

14- Fragments of irregularly rectangular to sub-rectangular sclereides with evenly thickened lignified walls.

15- Fragments of laticiferous tubes have granular contents, staining yellowishbrown with iodine.

16- Fragments show glands contain calcium carbonate.
17- Few starch granules, either free or in parenchyma cells are observed. They are simple, spherical with eccentric cleft hilum (appear in large ones).

18- Scattered clusters and prisms of calcium oxalate either free or enclosed in parenchymatous cells.

\section{THE INFLORESCENCE AND FRUIT}

\section{A- Macromorphology \\ The inflorescence and fruit (Fig. 8A,B\&C)}

The fruit is stalked syconium that is a succulent, hollow, spherical to oval-shaped, closed receptacle, enclosed within which are achene-like bodies, formed from numerous pistillate flowers lining the receptacle. Originally two kinds of female flowers are present in the fig; some long-styled (seed producing flowers) and others short-styled (gall-flowers) which have eggs laid in their ovaries and are sterile. The interior of the syconus contain numerous small achenes and eggs of the gall-wasp which brings pollination. Bracts and male flowers are at the upper part around the apical orifice (ostiolum) of the fruit. The proximal end is extended as a short stalk which widens below. The young fruit is rich in white latex found in tubes but disappear on ripening $^{31}$. It is green in color and has a faint odor and astringent taste. The ripe fruit is reddish-brown in color, odorless and has a sweet taste. It measures from 2 to $3 \mathrm{~cm}$ in length and 2 to $3 \mathrm{~cm}$ in diameter.

\section{The bract (Fig. 9D)}

It has lanceolate shape, acuminate apex and entire margin. It is colorless, sessile and measures about (4- $\underline{-}-6) \mathrm{mm}$ in length and (0.50.8-1.0) $\mathrm{mm}$ in width.

\section{The flowers ${ }^{1,13,32 \& 33}$}

Male flower (Fig. 9A)

It consists of 1-2 stamen of equal length. The filament is distinct, filiform, colorless (becomes brown in color after a while); measures about (388-558-729) $\mu \mathrm{m}$ in length and (330-422-515) $\mu \mathrm{m}$ in width. The anther is oval, grey in color and has two lobes, versatile, dehiscing longitudinally; varies in length from $0.59 \mathrm{~mm}$ to $1.10 \mathrm{~mm}$. 
Female flower (Fig. 9B)

It is superior unicarpellary, unilocular and colorless (becomes brown in color after a while). The ovary is oval in shape carrying filiform style and a stigma. The ovary contains one ovule in marginal placentation. The pistil measures about $(0.9-2.0-3.0) \mathrm{mm}$ in length and (0.25-0.44-0.64) $\mathrm{mm}$ in diameter.

\section{Gall flower (Fig. 9C)}

It is a sterile flower contains the egg of the insects; being about (0.66-0.99-1.32) $\mathrm{mm}$ in length and $(0.25-0.26-0.27) \mathrm{mm}$ in diameter.

\section{The calyx (Fig. 9E)}

It is formed of 3-5 united sepals arranged in one whorl. Each sepal has lanceolate shape, acute apex and entire margin. The surface is smooth and reticulated. It is colorless in young flower, while becomes brown in older one. It measures about (1.03-1.3-1.6) $\mathrm{mm}$ in length and $(0.053-\underline{0.078}-0.103) \mathrm{mm}$ in width.

\section{The receptacle (Fig. 8)}

It is succulent, spherical to oval in shape, green in colour when young and after maturation it becomes reddish brown. The surface is hairy with finely striated longitudinally. It measures about (1.7-2.4-3) $\mathrm{cm}$ in length and (2-2.5-3) $\mathrm{cm}$ in diameter.

\section{The stalk (Fig. 8A\&C)}

It is brownish-green, straight, cylindrical and solid with hairy surface. It measures (0.4$\underline{1.0}-1.9) \mathrm{cm}$ in length and $(0.2-\underline{0.3}-0.4) \mathrm{cm}$ in diameter.

\section{B- Micromorphology \\ The bract \\ The upper epidermis (inner surface) (Fig. 10A,B\&C)}

The epidermal cells vary in size and shape according to their position. In surface view, the cells at the apical region are polygonal, being more or less isodiametric with straight anticlinal walls. At the middle region, the cells are polygonal mainly isodiametric and elongated with straight anticlinal walls. Some cells contain cluster crystals of calcium oxalate. The cells at the basal region are polygonal, mainly isodiametric and elongated with straight anticlinal walls. The cells contain prisms and clusters crystals of calcium oxalate crystals. The upper epidermal cells are covered with smooth cuticle and contain brown pigment. Stomata and hairs are not observed.

The lower epidermis (outer surface) (Fig. 10D,E\&F)

It is more or less similar to those of the upper epidermis. The cells of the apical region are polygonal more or less isodiametric with straight anticlinal walls. At the middle region, the cells are polygonal and isodiametric. The cells at the basal region are polygonal and isodiametric with straight anticlinal walls. The epidermal cells contain brown pigment. Stomata and hairs are not observed.

\section{Male flower}

The filament (Fig. 11A)

The epidermal cells appear polygonal, axially elongated with straight anticlinal walls and covered with smooth cuticle.

\section{The anther}

Each anther is formed of 2 usually equal lobes which are attached together by the connective through which passes a small vascular strand continuous with that of filament. The connective is formed of small, thin-walled parenchyma. Each anther lobe contains 2 pollen sacs which are separated by soft septa formed of parenchyma.

\section{The epidermis of the anther (Fig. 11B\&C)}

The epidermal cells present at the periphery of the fibrous layer of the anther are polygonal with bar-like thickening, lignified walls. The cells contain prisms of calcium oxalate. The rest of the epidermis (Fig. 11C) is formed of papillosed cells which appear in surface view polygonal, more or less isodiametric cells with thin walls.

\section{The fibrous layer of anther (Fig. 11D)}

It consists of a single layer of lignified thick walled cells with bar-like thickening. This layer is continuous around 2 anther lobes except where the 2 pollen sacs meet. In surface view, the fibrous cells are more or less polygonal with distinctly beaded walls.

\section{The pollen grains (Fig. 11E)}

They are spherical with smooth exine. The mature pollen grains are grey in color. 


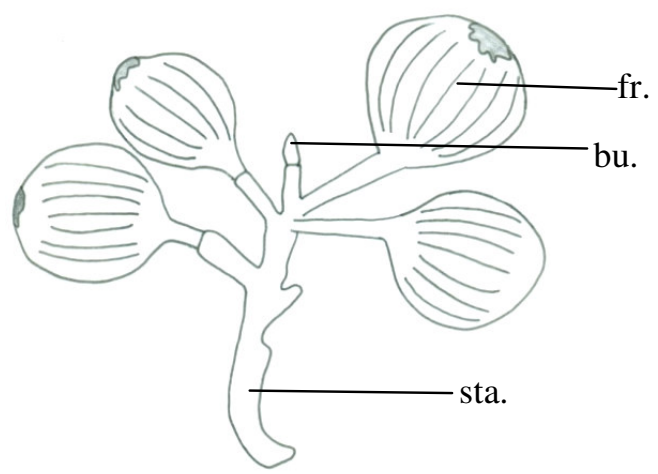

(A)

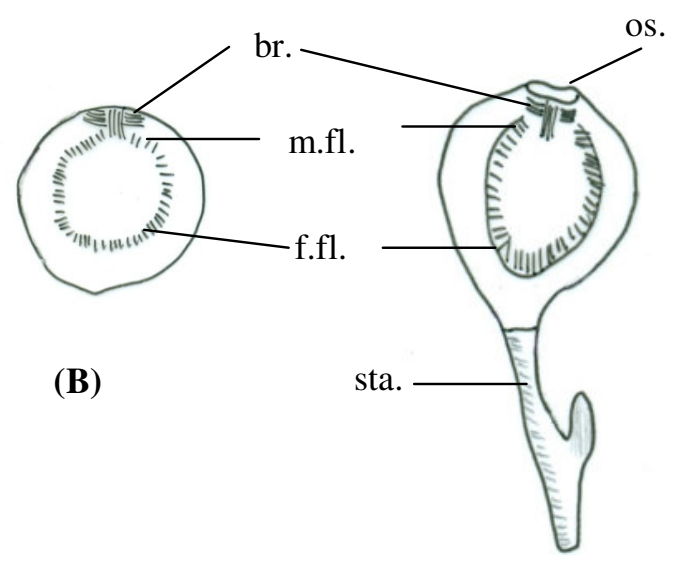

(C)

Fig. 8: (A) Macromorphology of the fruiting branch.

(B) Transverse section of the flowering inflorescence.

x 0.5

(C) Vertical section of the flowering inflorescence.

$\mathrm{x} 0.5$

br., bract; bu., bud; f.fl.,female flower; fr., fruit; m.fl., male flower; os., ostiolum; sta., stalk.

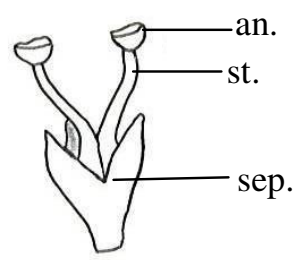

(A)

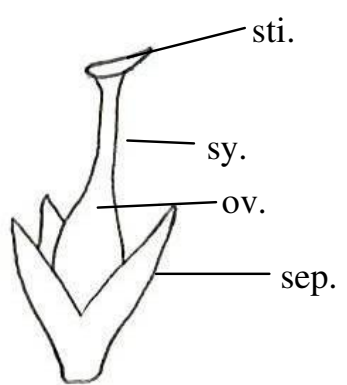

(B)

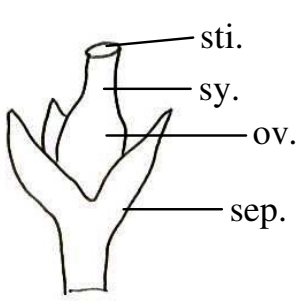

(C)
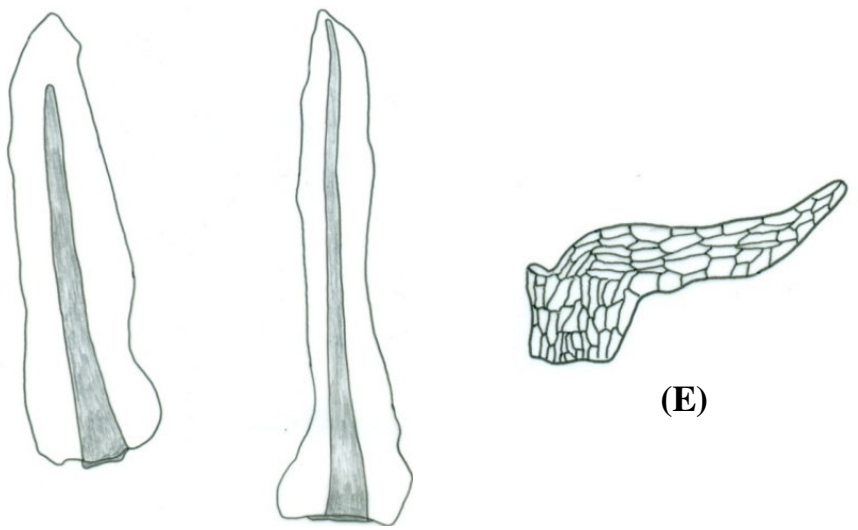

(E)

(D)

Fig. 9: (A) Male flower $\quad$ X30

(B) Long-styled female flower $\quad \mathrm{X} 8$

(C) Short-styled female flower (eventually becomes a gall). X20

(D) The bract $\quad \mathrm{X} 9$

$\begin{array}{ll}\text { (E) The sepal. } & \text { X60 }\end{array}$

an., anther; ov., ovary; sep., sepal; st., stamen; sti., stigma; sy., style. 


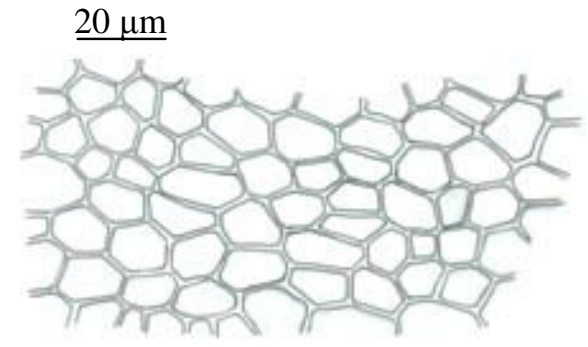

(A)

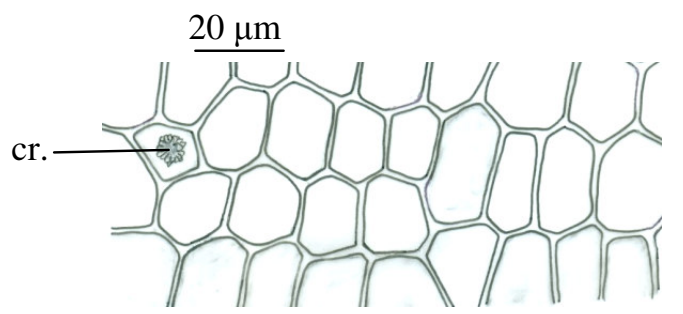

(B)

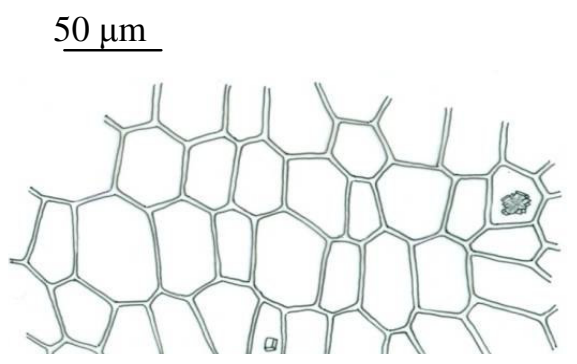

(C)

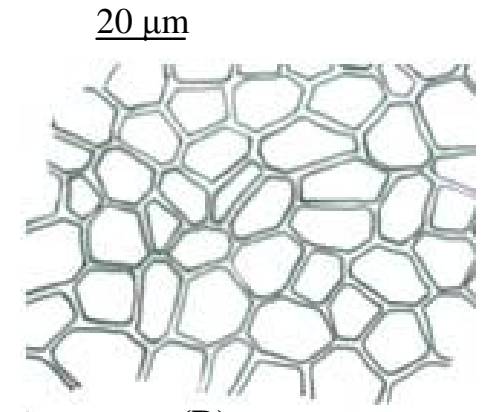

(D)

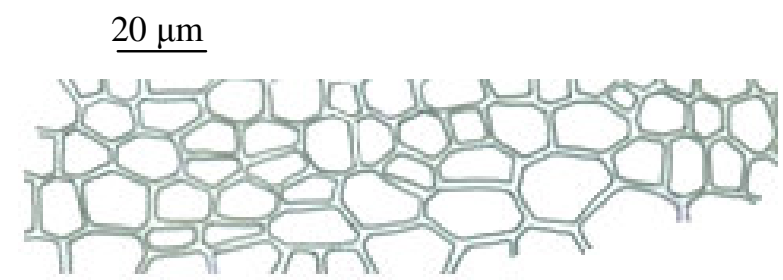

(E)

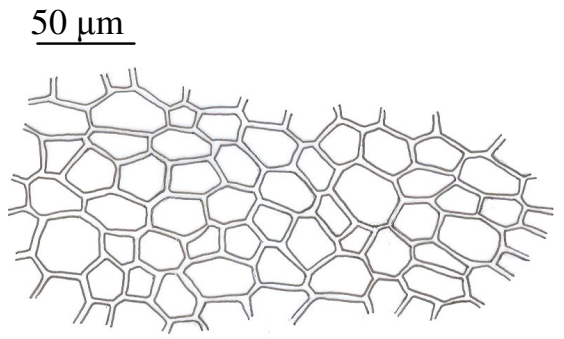

(F)

Fig. 10: Micromorphology of the bract.
(A) Apical upper epidermis.
(B) Middle upper epidermis.
(C) Basal upper epidermis.
(D) Apical lower epidermis.
(E) Middle lower epidermis.
(F) Basal lower epidermis.

cr., crystals of calcium oxalate. 


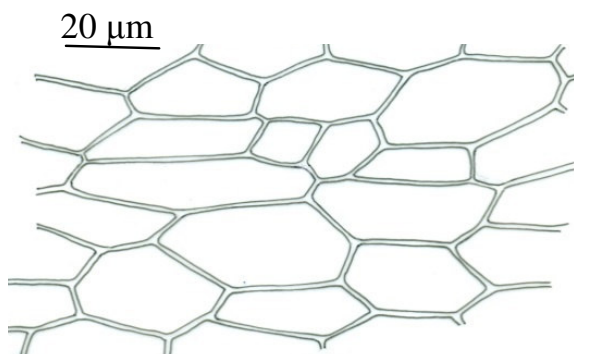

(A)

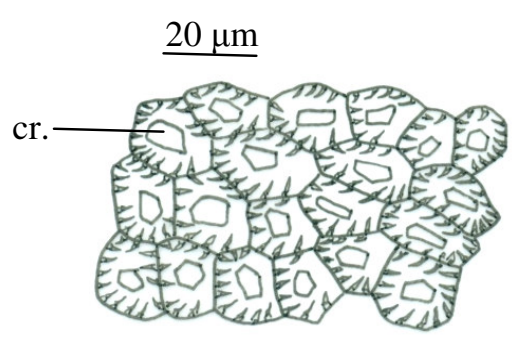

(B) $\underline{20 \mu \mathrm{m}}$

()

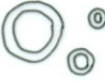

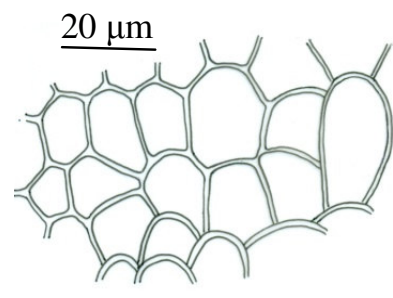

(C)

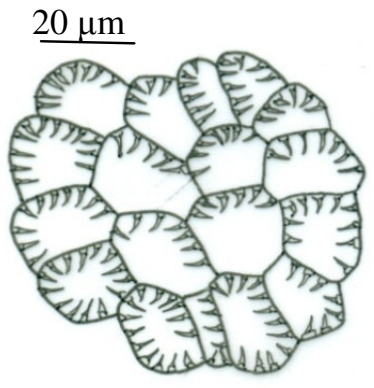

(D)

(E)

Fig. 11: (A) The epidermis of the filament.

(B) The epidermis at the periphery of fibrous layer of the anther.

(C) The epidermis of the anther.

(D) The fibrous layer of the anther.

(E) The pollen grains.

cr., crystals of calcium oxalate.

The stalk (Fig. 12A)

A transverse section in the stalk appears circular in outline showing multiple epidermis ${ }^{28}$ with outer hairy cells. The cortex shows outer collenchyma layer and an inner parenchymatous one. The vascular system is surrounded by parenchymatous pericycle showing few groups of pericyclic fibers. The phloem region is narrow and formed of soft cellulosic elements. The xylem region is somewhat wider and formed of lignified vessels, fibers, tracheids and xylem parenchyma. Medullary rays are almost uni- or biseriate. The phloem and xylem are separated by a cambial zone of 2-3 rows. The central pith is wide and formed of parenchymatous cells. The parenchyma cells of cortex and pith contain prisms and cluster crystals of calcium oxalate in addition to few starch grains which are mainly simple. Intraxyllary phloem is present at the periphery of the pith.

\section{The epidermis}

Epidermis consists of 1-3 row of rectangular to sub-rectangular cells covered with thin cuticle as seen in transverse section (Fig. 13). In surface view (Fig. 12B), the upper row of cells appear polygonal, somewhat axially elongated with straight anticlinal walls, covered with smooth cuticle. They contain brown pigment. Stomata are not observed. Few unicellular non-glandular trichomes are present which have acute to acuminate apices and sometimes curved. 


\section{The cortical tissue (Fig. 13)}

The outer layer consists of about 5 to 7 rows of collenchyma cells which are rounded to tangentially elongated. They contain prisms of calcium oxalate. This layer is followed by $7-$ 13 rows of rounded to tangentially elongated, thin walled parenchyma cells. They contain prisms and cluster crystals of calcium oxalate. Frequent latex tubes are scattered in parenchyma zone.

\section{The pericycle (Fig. 13)}

The pericycle is formed of parenchyma cells interrupted by small groups of pericyclic fibers. The pericyclic fibers have thick lignified walls, moderately wide lumina and tapering ends. Parenchyma cells contain prisms and cluster of calcium oxalate.
The vascular system (Fig. 13)

The phloem is formed of thin-walled soft cellulosic elements. The phloem parenchyma cells contain clusters of calcium oxalate. Few latex tubes are scattered. The xylem consists mainly of lignified spiral and scalariform vessels. Wood parenchyma cells are subrectangular axially elongated have thick lignified pitted walls. The medullary rays are uni- or biseriate and formed of elongated subrectangular non-lignified parenchyma cells in phloem region and lignified in xylem region.

\section{The pith (Fig. 13)}

The pith is formed of thin-walled parenchyma cells. They contain prisms and cluster crystals of calcium oxalate as well as starch granules. Few latex tubes are scattered. Intraxyllary phloem is scattered at the periphery of the pith.

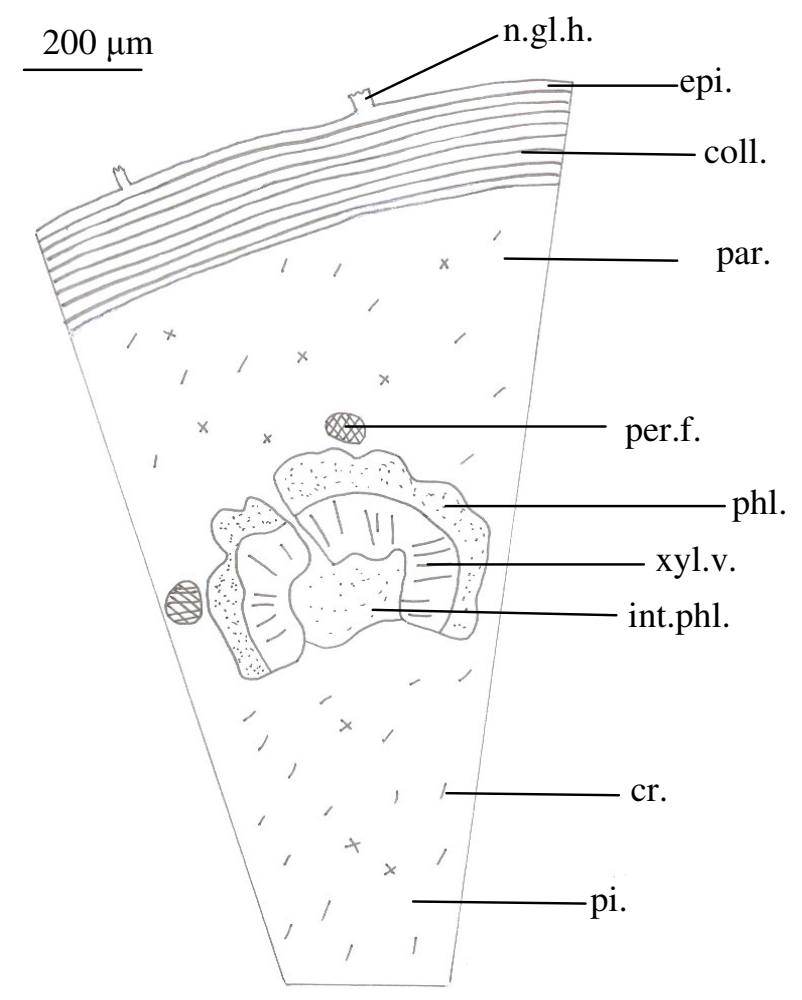

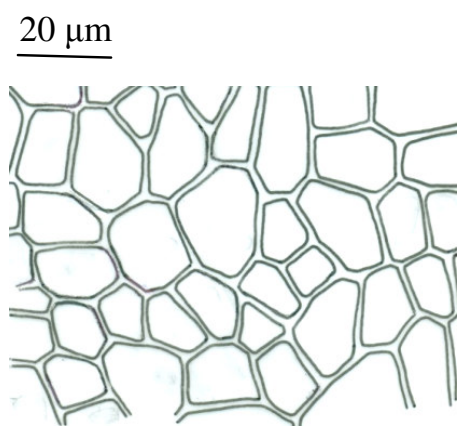

(B)

(A)

Fig. 12: The stalk:

$\begin{array}{ll}\text { (A) The diagrammatic T.S. } & \text { (B) The epidermis. }\end{array}$

coll., collenchyma; cr., crystal of calcium oxalate; ep., epidermis; int.phl., intraxylary phloem; n.gl.h., non-glandular hair; par., parenchyma; per.f., pericyclic fibers; phl., phloem; pi., pith; xyl.v., xylem. 

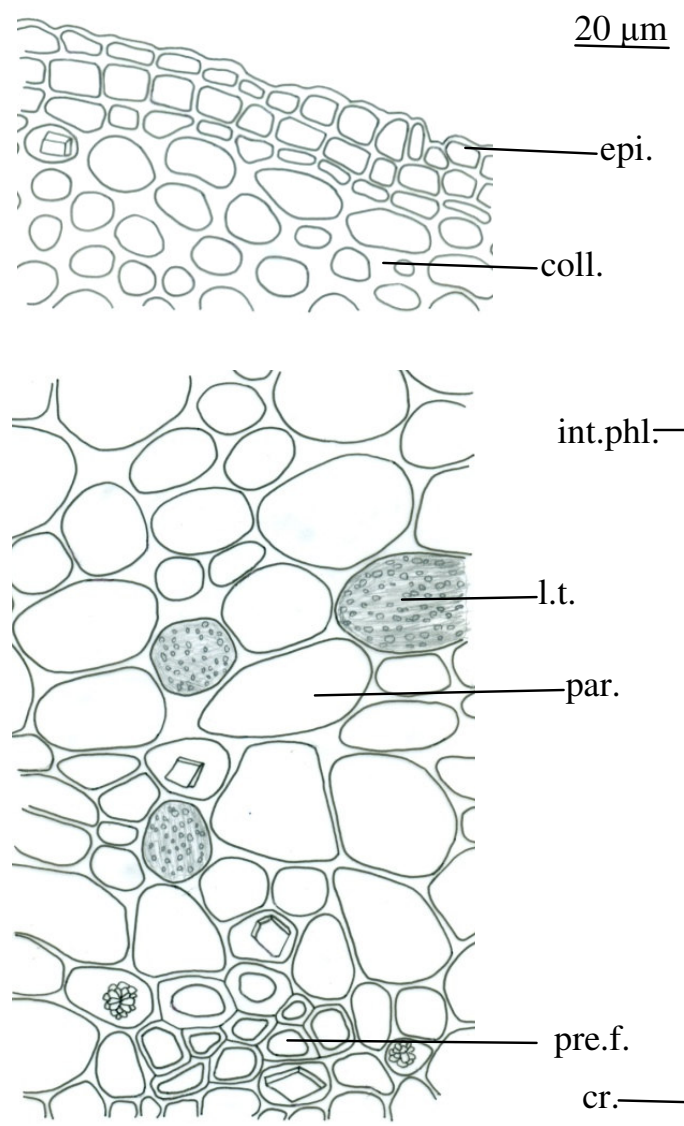
int.phl.
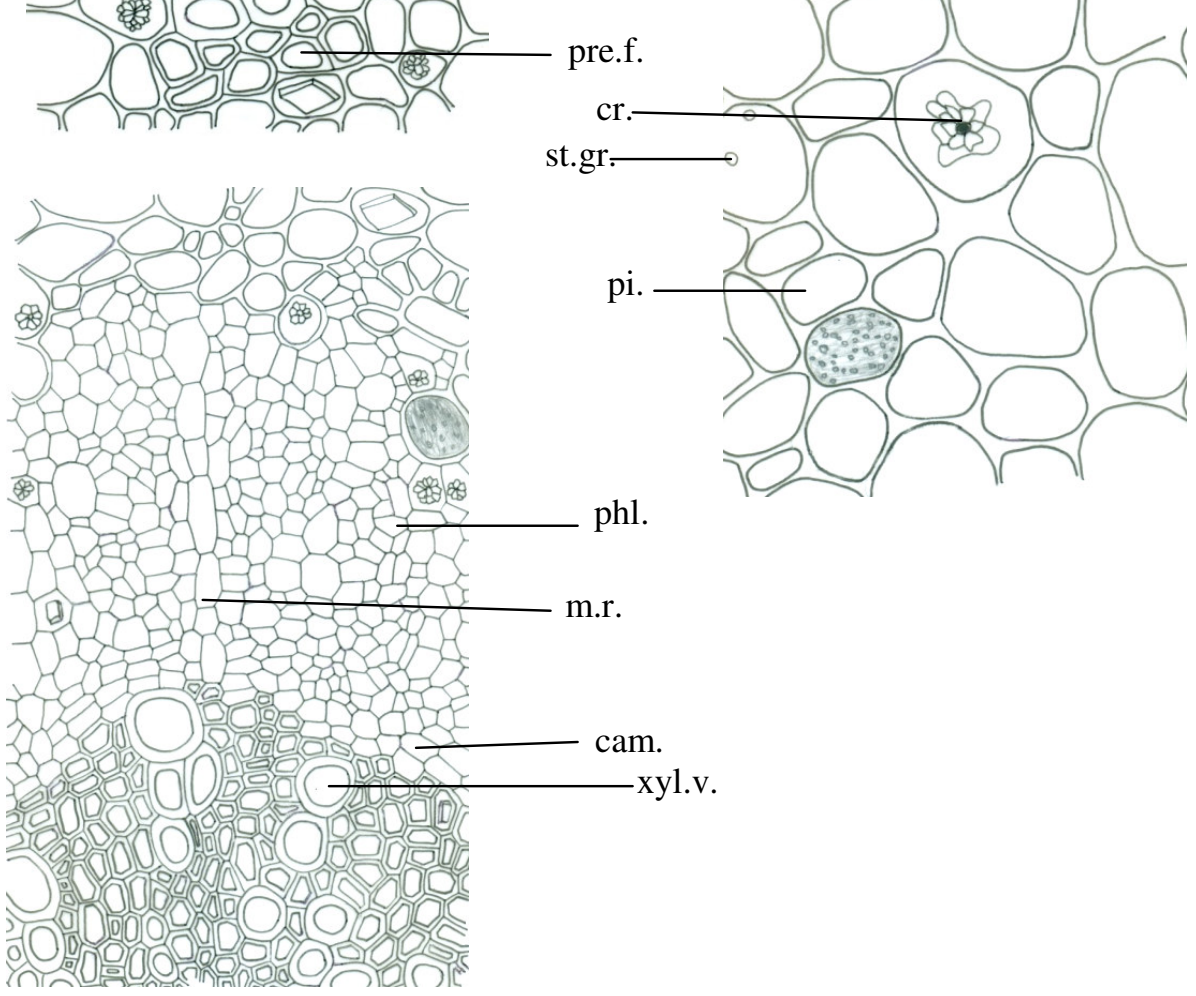

Fig. 13: Detailed T.S of the stalk.

cam., cambium; coll., collenchyma; cr., crystal of calcium oxalate; ep., epidermis; int.phl., intraxylary phloem; 1.t., laticiferous tube; m.r., medullary ray; par., parenchyma; per.f., pericyclic fibers; phl., phloem; pi., pith; st.gr., starch granules; xyl.v., xylem vessels. 
The receptacle (Fig. 14A)

A transverse section of the receptacle is circular in outline and shows an outer hairy epidermis followed by cortical tissue formed of an outer collenchyma layer and an inner parenchymatous layer. The vascular bundles are scattered through the parenchyma region. The phloem is narrow and formed of soft thinwalled cellulosic elements. The xylem is radiating and formed of lignified vessels, xylem parenchyma. The phloem and xylem are separated by a cambial zone of 2-3 rows. The medullary rays are uni- or biseriate. The inner zone of the cortical tissue shows pitted lignified parenchyma cells. Latex tubes and few simple starch granules are present. The inner epidermis consists of a single row which carries the flowers.

\section{The outer epidermis}

Outer epidermis consists of rectangular to sub-rectangular thick-walled cells arranged in one row and interrupted with non-lignified sclerenchyma cells as seen in transverse section (Fig. 15). In surface view, (Fig. 14B) the epidermal cells are polygonal somewhat axially elongated with thick straight anticlinal walls. Sclereides are isodiametric with thick, pitted and non-lignified walls. The cells contain brown pigment. Stomata of anomocytic type are present. Non-glandular hairs are present accompanied with few glandular ones. The glandular trichomes have unicellular heads and unicellular stalks. Non-glandular hairs are unicellular, with acute to acuminate sometimes curved apices. Long clothing hairs with basal pedestals of epidermal cells are observed.

At the orifice (Fig. 14C), the cells are similar to those of outer epidermis and showing unicellular non-glandular hairs. Stomata are not observed

\section{The middle region (Fig. 15)}

The outer zone consists of 2 rows of rounded, tangentially elongated collenchyma cells alternated with thick-walled non-lignified pitted sclerenchyma cells. The parenchyma is rounded, tangentially elongated cells. Frequent laticiferous tubes as well as cells containing protein granules are scattered in the parenchymatous zone. The vascular system consists of phloem which is formed of soft thin walled cellulosic elements followed by lignified spiral and scalariform vessels. The medullary rays are uni- or biseriate and formed of elongated sub-rectangular non-lignified parenchyma cells. Some of the parenchyma cells of the middle region are wide, pitted and lignified.

\section{The inner epidermis}

Inner epidermis is formed of small rectangular to sub-rectangular cells, covered with thin smooth cuticle as seen in the transverse section (Fig. 15). In surface view (Fig. 14D) the epidermal cells are polygonal somewhat axially elongated with straight anticlinal walls. Stomata and hairs are not observed.

At the orifice (Fig. 14E), the cells are polygonal, usually isodiameteric with straight anticlinal walls, covered with thin smooth cuticle and contain brown pigment. Stomata and hairs are not observed.

Isolated elements of the fruits (Fig. 16)

It is characterized microscopically by the following fragments:

1- Fragments of the upper epidermis of bract that vary in size and shape according to their position. The cells are polygonal, being more or less isodiametric with straight anticlinal walls covered with smooth cuticle. Some cells contain clusters and prisms of calcium oxalate. They contain brown pigment. Stomata and hairs are not observed.

2- Fragments of the lower epidermis of bract which are polygonal, isodiametric with straight anticlinal walls usually similar to those of the upper epidermis in all contents but they are free from calcium oxalate crystals.

3- Scattered entire or fragments of glandular and non-glandular hairs. The glandular trichomes have unicellular heads and unicellular stalks. Non-glandular hairs are unicellular, with a acute to acuminate sometimes curved apices. Long clothing hairs with basal pedestals of epidermal cells are observed.

4- Fragments of the epidermis of the filament show polygonal, axially elongated cells with straight, anticlinal walls and covered with smooth cuticle. 

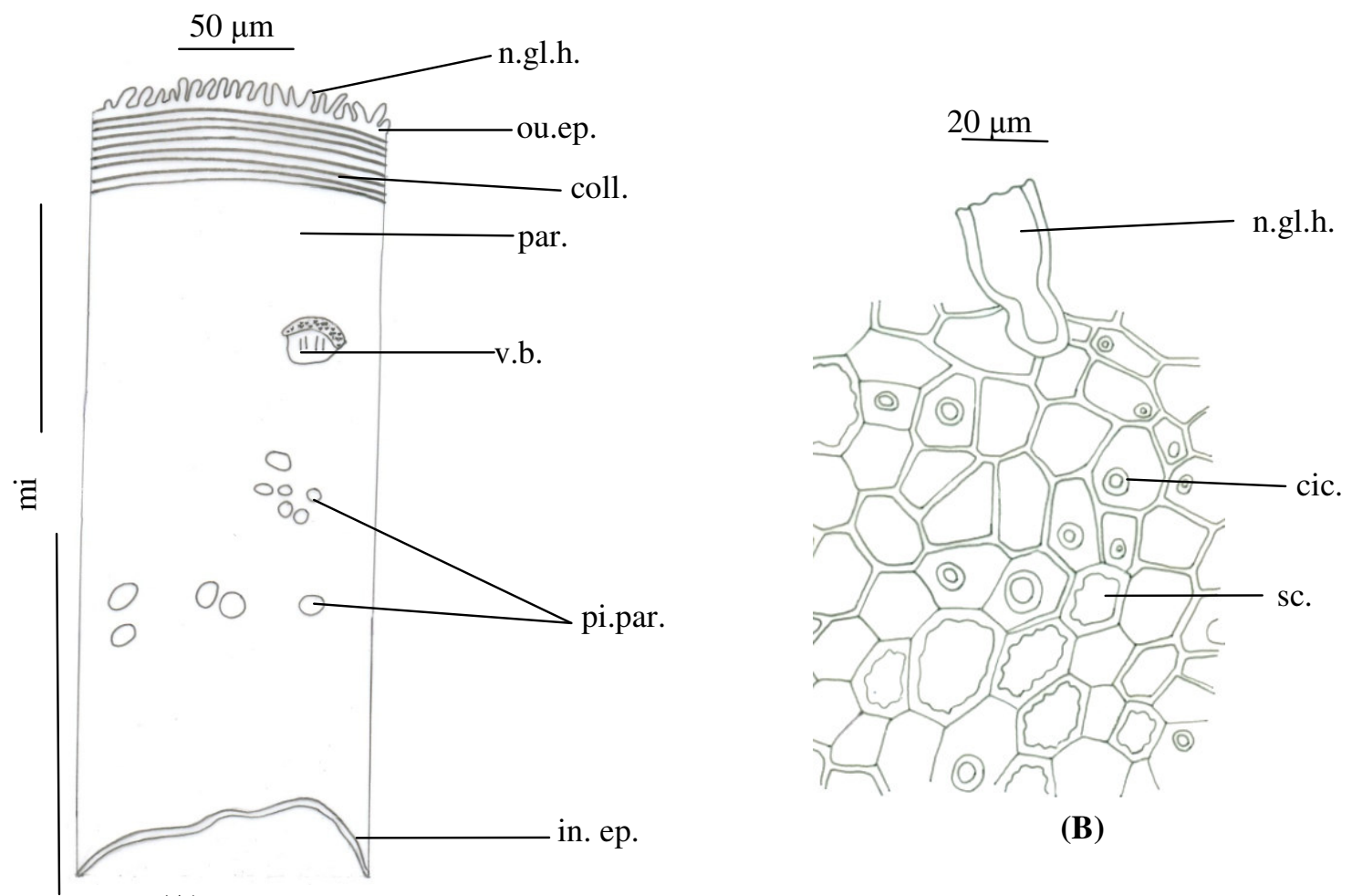

(A)

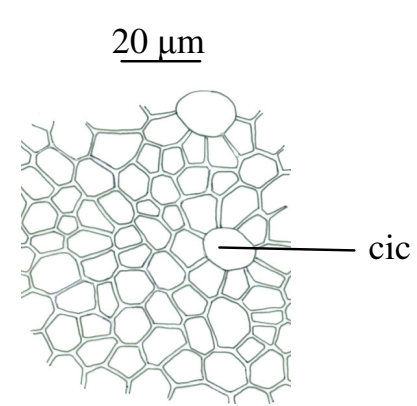

(C)

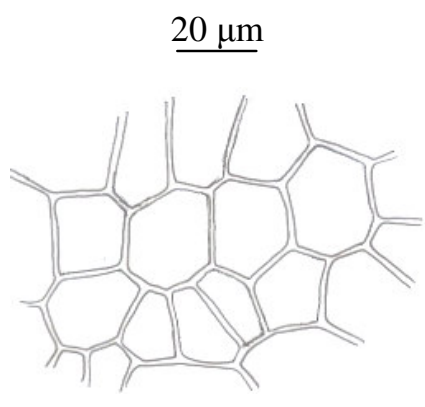

(D)

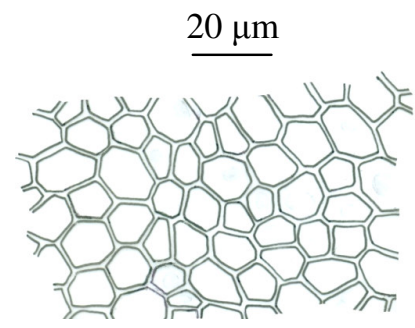

(E)

Fig. 14: (A) The diagrammatic T.S. of the receptacle.

(B) The outer epidermis of the receptacle.

(C) The outer epidermis of the receptacle at the orifice.

(D) The inner epidermis of the receptacle.

(E) The inner epidermis of the receptacle at the orifice.

cic., cicatrix; coll., collenchymas; in.ep., inner epidermis; mi., middle region; n.gl.h., non-glandular hair; ou.ep., outer epidermis; par., parenchyma; pi.par., pitted parenchyma; sc., sclereides; v.b., vascular bundles. 

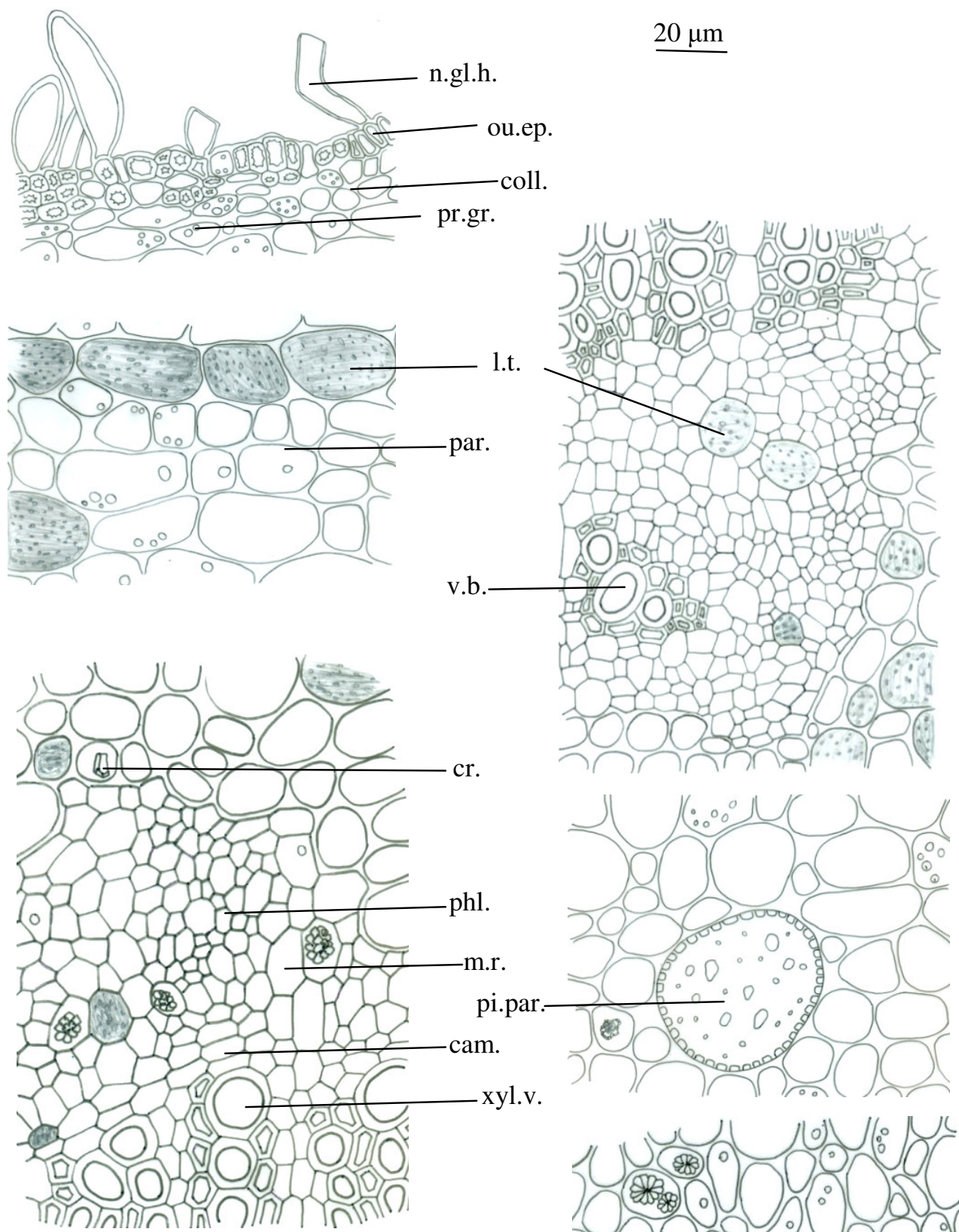

in.ep

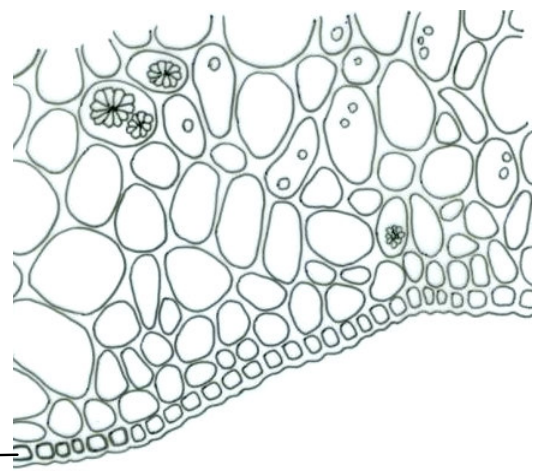

Fig. 15: Detailed T.S of the receptacle.

cam., cambium; coll., collenchyma; cr., crystal of calcium oxalate; in.ep., inner epidermis; m.r., medullary ray; n.gl.h., non-glandular hair; ou.epi., outer epidermis; 1.t., laticiferous tube; par., parenchyma; phl., phloem; pi.par., pitted parenchyma; pr.gr., protein granules; v. b., vascular bundle; xyl.v., xylem vessels. 


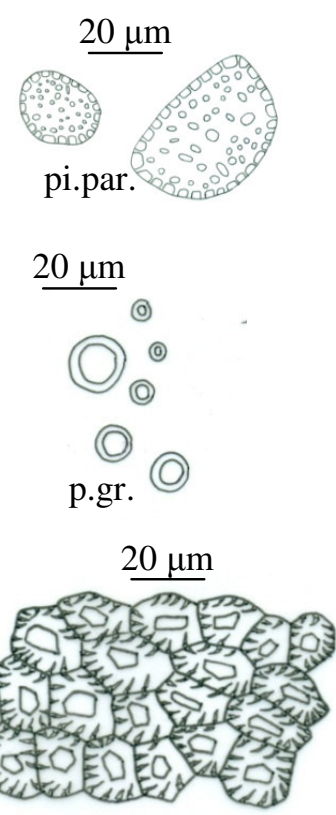

ep.an

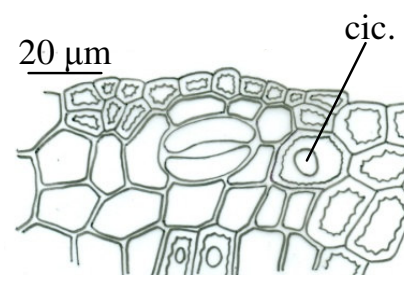

ou.epi.re.

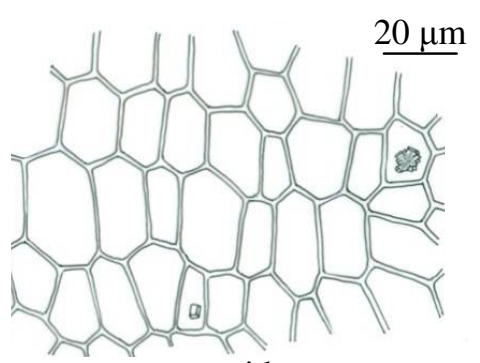

epi.br.

$20 \mu \mathrm{m}$

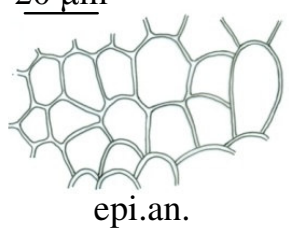

epi.an.

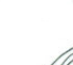

18

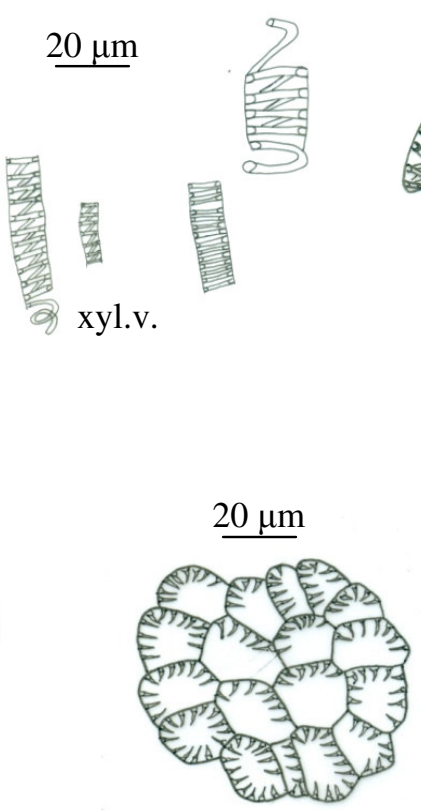

fib.l

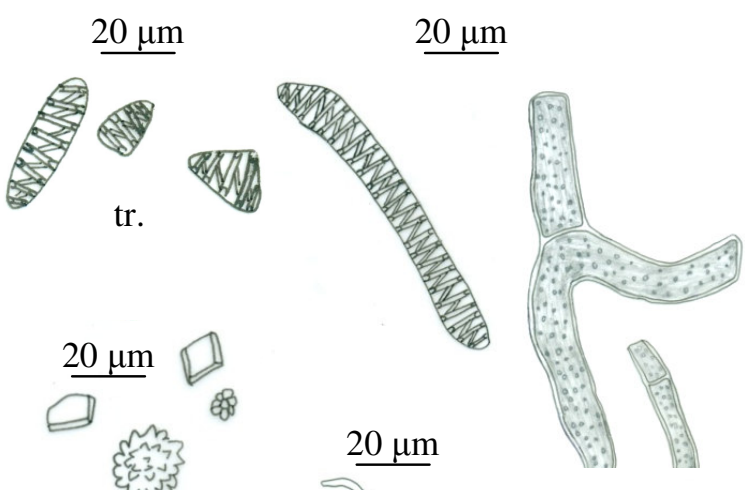

1.t.

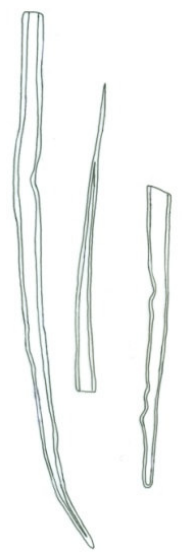

per.f.

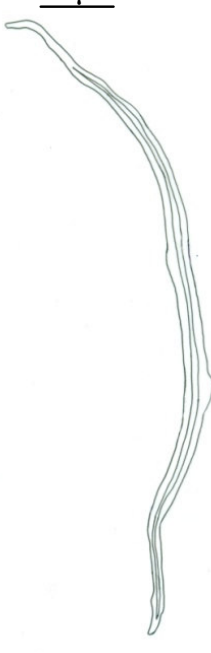

cr.

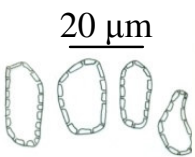

sc.re.

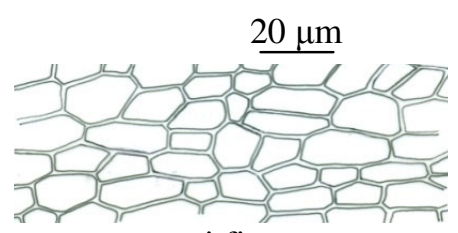

epi.fi.

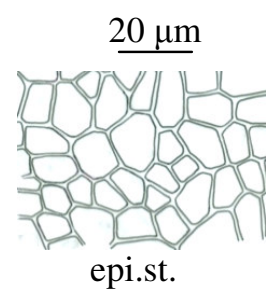

n.gl.h.

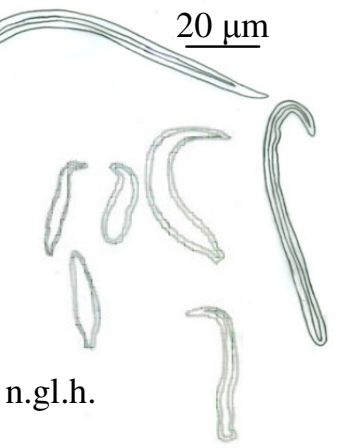

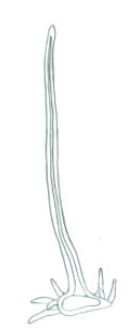

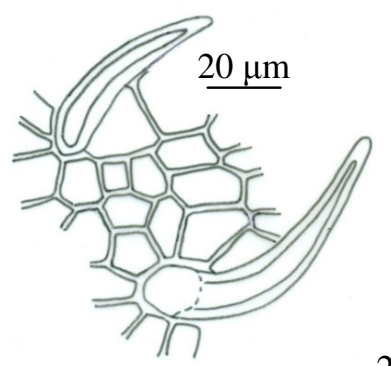

ou.epi.re.or.

$\underline{20 \mu \mathrm{m}}$

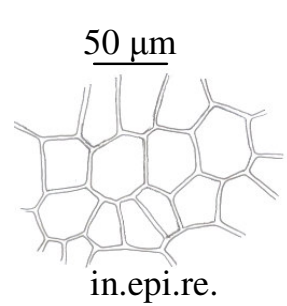

gl.h.

Fig. 16: Isolated elements of the fruits.

cic., cicatrix; cr., crystal of calcium oxalate; ep. an., epidermal cells of anther; epi.br., epidermis of the bract; epi.fi., epidermis of the filament; epi.st., epidermis of the stalk; fib.l., fibrous layer of anther; 1.t., laticiferous tube; gl.h., glandular hair; in.epi.re., inner epidermis of receptacle; n.gl.h., non-glandular hair; ou.epi.re., outer epidermis of receptacle; ou.epi.re.or., outer epidermis of the receptacle at the orifice; per.f., pericyclic fiber; p.gr., pollen grains; pi.par., pitted parenchyma; sc.re., sclerenchyma cells of receptacle; tr., tracheids; xyl.v., xylem vessels. 
5- Fragments of fibrous layer of anther show more or less polygonal, nearly hexagonal cells with beaded walls and bar-like thickening.

6- Pollen grains are spherical in shape, grey in color, with thin wall and relatively smooth exine.

7- Fragments of the epidermal cells of the anther that are polygonal with bar-like thickening, lignified walls and contain prisms of calcium oxalate.

8- Fragments of elongated sub-rectangular tracheids from fruit.

9- Fragments of the epidermis of stalk appear polygonal, somewhat axially elongated with thick straight anticlinal walls, covered with smooth cuticle and carrying unicellular, non-glandular hairs.

10- Fragments showing sclerenchyma cells from the receptacle which are irregularly rectangular to sub-rectangular in shape with evenly thickened non-lignified walls.

11- Fragments of lignified spiral and scalariform xylem vessels.

12- Lignified pericyclic fibers from the stalks with moderately thick walls, narrow to moderately wide lumina, acute to acuminate tapering ends.

13- Laticiferous tubes have granular contents, staining yellowish-brown with iodine.
14- Fragments of the outer epidermis of the receptacle showing polygonal, somewhat axially elongated cells with thick straight anticlinal walls; accompanied with polygonal thick non-lignified pitted sclerenchyma. The cells contain brown pigment. Stomata of anomocytic type, non-glandular trichomes accompanied by few glandular ones are present. The glandular trichomes have unicellular heads and unicellular stalks. Nonglandular hairs are unicellular, with acute to acuminate sometimes curved apices. Long clothing hairs with basal pedestals of epidermal cells are observed. At the orifice the cells are polygonal, usually isodiameteric with straight anticlinal walls and contain brown pigment. Stomata are not observed. Unicellular non-glandular hairs are present that have acute to acuminate sometimes curved apices.

15- Fragments of papillosed cells of epidermis of the anther appear polygonal, more or less isodiametric with thin walls.

16- Pitted lignified parenchyma from the middle region of receptacle.

17- Abundent clusters and prisms of calcium oxalate.

Table 1: Microscopical measurements of leaves and fruits of F. sycomorus L. (in microns).

\begin{tabular}{|c|c|c|c|c|}
\hline Item & Length & Width & Diameter & Height \\
\hline \multicolumn{5}{|l|}{ Lamina } \\
\hline Upper epidermis & $17-\underline{28-39}$ & $12-\underline{24-37}$ & & $16-\underline{26}-37$ \\
\hline Lower epidermis & $21-\underline{29-38}$ & 9-13-17 & & 8- $\underline{15-22}$ \\
\hline Neural epidermis & $17-21-26$ & & & \\
\hline Stomata & 16-19-22 & & $11-12-13$ & \\
\hline Palisade & 46- $\underline{64-83}$ & $12-\underline{18}-24$ & 8-11-15 & \\
\hline Parenchyma & & & 14-17-29 & \\
\hline Collenchyma & & & $11-\underline{13}-17$ & \\
\hline \multicolumn{5}{|l|}{ Chlorenchyma } \\
\hline Pericyclic fibre & $537-677-818$ & & 13-14-15 & \\
\hline Xylem vessel & & & $40-67-94$ & \\
\hline Wood fiber & 534-669-805 & & $12-17-22$ & \\
\hline Tracheid & 40- $\underline{86}-132$ & $18-26-35$ & & \\
\hline Wood parenchyma & $73-77-81$ & 24-27-31 & & \\
\hline Medullary ray & $30-34-38$ & $27-31-35$ & & \\
\hline Cluster & & & $4.2-\underline{-9}-14.7$ & \\
\hline Prism & 16.8-17-19 & & & \\
\hline Glandular hair & $14.3-19-23.8$ & & $9.5-13-17.1$ & \\
\hline
\end{tabular}


Table 1: Continued

\begin{tabular}{|c|c|c|c|c|}
\hline Item & Length & Width & Diameter & Height \\
\hline $\begin{array}{l}\text { Non-glandular hair: } \\
\text { a-short hair } \\
\text { b-long clothing hair }\end{array}$ & $\begin{array}{c}102-\underline{188}-274 \\
379.3-581-783.3\end{array}$ & $\begin{array}{c}11-\underline{13}-15 \\
12.5-\underline{27}-41.5\end{array}$ & & \\
\hline \multicolumn{5}{|l|}{ Petiole } \\
\hline Epidermis & $10-\underline{30-53}$ & $12-\underline{16}-21$ & & 5- $\underline{9-13}$ \\
\hline Parenchyma & & & $20-\underline{32-45}$ & \\
\hline Collenchyma & & & $9-15-22$ & \\
\hline Pericyclic fiber & 132-143-154 & & $11-\underline{11-12}$ & \\
\hline Xylem vessel & & & $18-\underline{26}-41$ & \\
\hline Wood fibre & 74-93-112 & & $11-\underline{14-18}$ & \\
\hline Wood parenchyma & $60-\underline{67-70}$ & $22-\underline{23}-24$ & & \\
\hline Tracheid & $69-79-90$ & $22-\underline{26-31}$ & & \\
\hline Medullary ray & $16-\underline{29-43}$ & 29-33-37 & & \\
\hline Cluster & & & 4.2-11-19 & \\
\hline Prisms & 9.5-14-20 & & & \\
\hline $\begin{array}{l}\text { Non-glandular hair: } \\
\text { a-short hair } \\
\text { b-long clothing hair }\end{array}$ & $\begin{array}{c}56-79-128 \\
115-\underline{433}-752.1 \\
\end{array}$ & $\begin{array}{l}10-\underline{14}-15 \\
9-\underline{13}-18.8 \\
\end{array}$ & & \\
\hline Starch & & & $1.1-\underline{-2}-4.2$ & \\
\hline \multicolumn{5}{|l|}{ Inflorescence } \\
\hline \multicolumn{5}{|l|}{ Bract } \\
\hline Upper epidermis (Apical) & $14-\underline{23}-32$ & $16-\underline{19}-22$ & & \\
\hline Upper epidermis (Middle) & $17-\underline{23}-30$ & $22-\underline{26-30}$ & & \\
\hline Upper epidermis (Basal) & $42-\underline{58-74}$ & $21-\underline{31-42}$ & & \\
\hline Lower epidermis (Apical) & 7-12-18 & 6-11-16 & & \\
\hline Lower epidermis (Middle) & $5-\underline{10-15}$ & $7-\underline{12-18}$ & & \\
\hline Lower epidermis (Basal) & $17-\underline{25-34}$ & 14- $\underline{16-18}$ & & \\
\hline \multicolumn{5}{|l|}{ Male flower } \\
\hline Pollen grain & & & & $3.4-16-29$ \\
\hline Fibrous layer of anther & 106-151-197 & 77-107-138 & & \\
\hline Epidermis of anther & 7.8-11-15.6 & 5.6-11-17.8 & & \\
\hline Epidermis of anther & $20-\underline{28-37}$ & $15-\underline{25-36}$ & & \\
\hline Epidermis of filament & $10-\underline{21-33}$ & $13-\underline{19-25}$ & & \\
\hline \multicolumn{5}{|l|}{ Stalk } \\
\hline Epidermal cell & $7-\underline{16}-25$ & $9-\underline{10-12}$ & 8-11-14 & \\
\hline Collenchyma & & & & 8-18-29 \\
\hline Parenchyma of cortex & & & & $15-\underline{31-48}$ \\
\hline Pericyclic fiber & $129.5-204-278.9$ & $4.2-\underline{7}-10.5$ & & \\
\hline Xylem vessel & & & & 4-10-16 \\
\hline Parenchyma of pith & & & & $18-\underline{35-53}$ \\
\hline \multicolumn{5}{|l|}{ Receptacle } \\
\hline $\begin{array}{l}\text { Outer epidermis } \\
\text { Outer epidermis at the orifice }\end{array}$ & $\begin{array}{c}92-\underline{137-183} \\
5-11-17\end{array}$ & $\begin{array}{c}102-\underline{-134-167} \\
4-\underline{9-15}\end{array}$ & $9-\underline{10-12}$ & \\
\hline Sclerenchyma & $4.2-\underline{7}-10.5$ & $4.2-9-14.7$ & & \\
\hline Parenchyma & & & & $16-\underline{34-54}$ \\
\hline Xylem vessel & & & & 6-12-19 \\
\hline $\begin{array}{l}\text { Inner epidermis } \\
\text { Inner epidermis at the orifice }\end{array}$ & $\begin{array}{l}8-\underline{13}-18 \\
4-\underline{9}-15\end{array}$ & $\begin{array}{c}4-\underline{6}-8 \\
5-\underline{9}-13 \\
\end{array}$ & $17.9-\underline{27}-37.5$ & \\
\hline \multicolumn{5}{|l|}{ General elements } \\
\hline Stomata & $18.1-26-34$ & & & $14.2-21-29.6$ \\
\hline Non-glandular hair & 58- $\underline{-81-105}$ & $13-\underline{16}-19$ & & \\
\hline Cluster & & & & 6- $\underline{9-12}$ \\
\hline Prism & $6-\underline{9-12}$ & & & \\
\hline
\end{tabular}




\section{REFERENCES}

1- G. H. M. Lawrence, "Taxonomy of Vascular Plants", Macmillan Co., New York, 1951, pp. 462-463.

2- L. E. Core, "Plant Taxonomy", Prentice Hall, Englewood Cliffs, New Jersey, 1955, pp. 295-297.

3- G. L. Chopra, "Angiosperms (Systematic \& Life-cycle)", $11^{\text {th }}$ Ed, S. Nagin \& Co., Educational publishers \& Booksellers, Jullunder, Delhi, 1973, pp. 406-413.

4- S. F. Farag, "Phytochemical and pharmacological studies of Ficus benjamina L. leaves", Mansoura J. Pharm. Sci., 21 (2), 19-36 (2005).

5- E. P. Lansky, H. M. Paavilainena, A. D. Pawlus and R. A. Newman, "Ficus spp. (fig): Ethnobotany and potential as anticancer and anti-inflammatory agents", J. Ethnopharmacol., 119, 195-213 (2008).

6- M. A. Ramadan, A. S. Ahmad, A. M. Nafady and A. I. Mansour, "Chemical composition of the stem bark and leaves of Ficus pandurata Hance", Nat. Prod. Res., 23 (13), 1218-1230 (2009).

7- S. Mawa, K. Husain and I. Jantan, "Ficus carica L. (Moraceae): Phytochemistry, traditional uses and biological activities", Evid.-Based Complement. Alternat. Med., doi: 10.1155/2013/974256, 1-8 (2013).

8- P. Somwong, R. Suttisri and A. Buakeaw, "New sesquiterpenes and phenolic compound from Ficus foveolata", Fitoterapia, 85 (e1-e8), 1-7 (2013).

9- P. V. Kiem, N. X. Cuong, N. X. Nhiem, V. K. Thu, N. K. Ban, C. V. Minh, B. H. Tai, T. N. Hai, S. H. Lee, H. D. Jang and Y. H. Kim, "Antioxidant activity of a new C-glycosylflavone from the leaves of Ficus microcarpa", Bioorg. Med. Chem. Lett., 21 (2), 633-637 (2011).

10- E. J. T. Mbosso, J. C. A. Nguedia, F. Meyer, X. N. Lenta, S. Ngouela, B. Lallemand, V. Mathieu, P. V. Antwerpen, A. L. Njunda, D. Adiogo, E. Tsamo, Y. Looze, R. Kiss and R. Wintjens, "Ceramide, cerebroside and triterpenoid saponin from the bark of aerial roots of
Ficus elastica
(Moraceae)", Phytochemistry, 83, 95-103, doi:10.1016/j.phtochem.

2012.07.010 (2012).

11- A. G. Damu, P.-C. Kuo, L.-S. Shi, C.-Y. Li, C.-R. Su and T.-S. Wu, "Cytotoxic phenanthroindolizidine alkaloids from the roots of Ficus septica", Planta Med., 75 (10), 1152-1156 (2009).

12- M. N. El-Hadidi and L. Boulos, "Street Trees in Egypt", Cairo University Press, Cairo, 1979, pp. 52-64.

13- R. Muschler, "A Manual Flora of Egypt", J. Cramer, S-H Service Agency in Lehre, New York, 1970, pp. 244-249.

14- J. M. Watt and M. G. Breyer-Brandwijk, "The Medicinal and Poisonous Plants of Southern and Eastern Africa", Livingstone. Ltd., London, 1962, pp.773780.

15- S. H. Garba, J. Prasad and U. K. Sandabe, " Hepatoprotective effect of the aqueous root-bark extract of Ficus sycomorus (Linn.) on carbon tetrachloride induced hepatotoxicity in rats", J. Biol. Sci., 7 (2), 276-281 (2007).

16- S. H. H. El-Gayed, "Pharmacognostical Study of Certain Ficus Species Growing in Egypt", Ph.D. Thesis, Faculty of Pharmacy, Cairo University (2000).

17- S. H. M. Bekheet, F. F. Abdel-Motaal and U. A. Mahalel, "Antifungal effects of Ficus sycomorus and Pergularia tomentosa aqueous extracts on some organs in Bufo regularis treated with Aspergillus niger", Tissue Cell, 43 (6), 398-404 (2011).

18- A. G. Olusesan, O. C.-L. Ebele, O. N. Onwuegbuchulam and E. J. Olorunmola, "Preliminary in-vitro antibacterial activities of ethanolic extracts of Ficus sycomorus Linn. and Ficus platyphylla Del. (Moraceae)", Afr. J. Microbiol. Res., 4 (8), 598-601 (2010).

19- G. Ibrahim, M. Yusuf and H. M. Yaro, "Antinociceptive and anti-inflammatory effects of Ficus ingens (Moraceae)", Nig. J. Nat. Prod. Med., 10, 63-65 (2006).

20- A. A. Ahmadu, A. U. Zezi and A. H. Yaro, "Anti-diarrheal activity of the leaf extract of Daniella oliveri Hutch and Dalz (Fabaceae) and Ficus sycomorus Miq. (Moraceae)", Afr. J. Trad. Comp. Alt. Med., 4 (4), 524-528 (2007). 
21- M. M. El-Sayed, M. A. Mahmoud, H. A. El-Nahas, S. A. El-Toumy, E. A. El-Wakil and M. A. Ghareeb, "Bio-guided isolation and structure elucidation of antioxidant compounds from the leaves of Ficus sycomorus", Pharmacologyonline, 3, 317332 (2010).

22- M. M. El-Sayed, A. M. Abdel-Hadi, A. A. Sabra, M. A. Mahmoud, E. A. El-Wakil and M. A. Ghareeb, "Effect of Ficus sycomorus and Azadirachta indica extracts on liver state of mice infected with Schistosoma mansoni", J. Egypt. Soc. Parasitol., 41 (1), 77-88 (2011).

23- U. K. Sandabe, P. A. Onyeyili and G. A. Chibuzo, "Sedative and anticonvulsant effects of aqueous extract of Ficus sycomorus L. (Moraceae) stem bark in rats", Veterinarski Arhiv, 73 (2), 103-110 (2003).

24- O. Mousa, P. Vuorela, J. Kiviranta, S. Abdel Wahab, R. Hiltunen and $\mathrm{H}$. Vuorela, "Bioactivity of certain Egyptian Ficus species", J. Ethnopharmacol., 41 (1-2), 71-76 (1994).

25- O. A. Rashwan, "Pharmacognostical Study of Certain Plants Belonging to Family Moraceae", M. Sc. Thesis, Faculty of Pharmacy, Cairo University (1980).

26- U. K. Sandabe, P. A. Onyeyili and and G. A. Chibuzo, "Phytochemical screening and effect of aqueous extract of Ficus sycomorus L. (Moraceae) stem bark on muscular activity in laboratory animals", J. Ethnopharmacol., 103 (3), 481-483 (2006).
27- A. A. Romeh, "Phytochemicals from Ficus sycomorus L. leaves act as insecticides and acaricides", Afr. J. Agric. Res., 8 (27), 3571-3579 (2013).

28- K. Esau, "Plant Anatomy", $2^{\text {nd }} E d$, Wily Eastern Private Ltd., New Delhi, 1965, p. 175.

29- S. M. El-Sayyad, H. M. Sayed and A. A. Attia, "Macro- and micromorphology of the stems and leaves of Ficus platyphylla (Del.)", Bull. Pharm. Sci, Assiut University, 10 (2), 103-122 (1987).

30- C. R. Metcalfe and L. Chalk, "Anatomy of Dicotyledons", The Clarendon Press, Oxford, Vol. II, 1950, pp. 1259-1271.

31- A. H. Saber, "Practical Pharmacognosy with a General Study of Plant Organs", $4^{\text {th }}$ Ed, Al Shaab Printing House, U.A.R., 1966, pp. 163-164.

32- K. R. Kirtikar and B. D. Basu, "Indian Medicinal Plants", $2^{\text {nd }} E d$, Vol. III, Oxford University Press, London, 1969, pp. 23092310.

33- K. Müller-Hohenstein, E. Beck and E.-D. Schulze, "Plant Ecology", Springer, Berlin, Heiglberg, 2005, p. 592. 


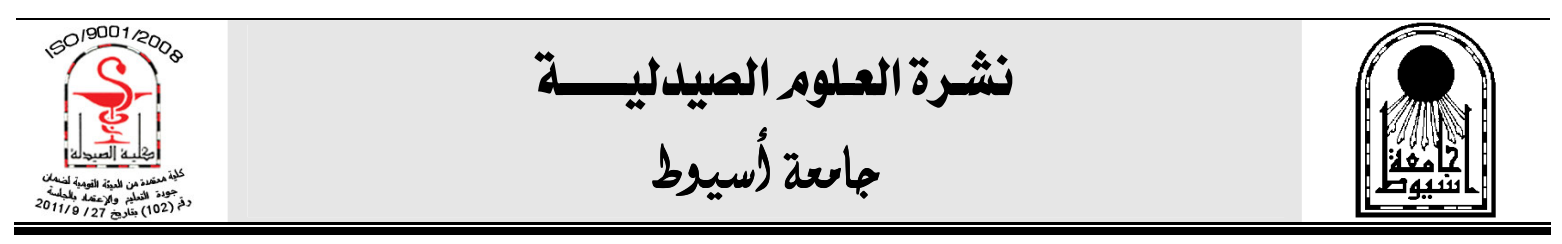

دراسة عيانية ومجهرية لأوراق ونورات وثمار نبات فيكس سيكومورس ل.

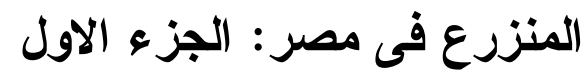

سامية محمد الصياد - مقبول احمد مقبول - سلوى فاروق فرج - رفيدة مصطفى على فئ هُعز الاول قسم العقاقير ، كلية الصيدلة ، جامعة اسيوط ، اسيوط ، مصر

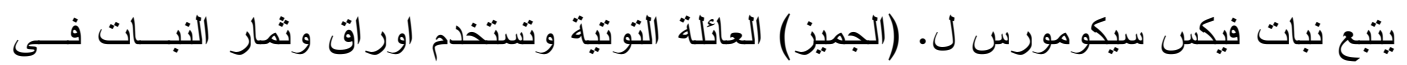

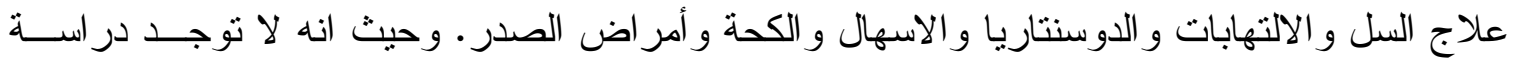

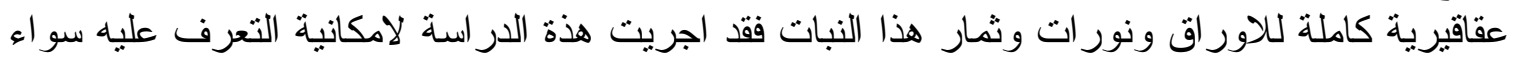

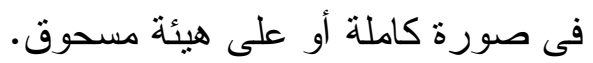

